\title{
Tree growth stress and related problems
}

\author{
Joseph Gril $^{1} \cdot$ Delphine Jullien ${ }^{1} \cdot$ Sandrine Bardet $^{1} \cdot$ Hiroyuki Yamamoto $^{2}$
}

Received: 23 May 2016/Accepted: 15 May 2017/Published online: 29 June 2017

(c) The Author(s) 2017. This article is an open access publication

\begin{abstract}
Tree growth stress, resulted from the combined effects of dead weight increase and cell wall maturation in the growing trees, fulfills biomechanical functions by enhancing the strength of growing stems and by controlling their growth orientation. Its value after new wood formation, named maturation stress, can be determined by measuring the instantaneously released strain at stem periphery. Exceptional levels of longitudinal stress are reached in reaction wood, in the form of compression in gymnosperms or higher-than-usual tension in angiosperms, inspiring theories to explain the generation process of the maturation stress at the level of wood fiber: the synergistic action of compressive stress generated in the amorphous ligninhemicellulose matrix and tensile stress due to the shortening of the crystalline cellulosic framework is a possible driving force. Besides the elastic component, growth stress bears viscoelastic components that are locked in the matured cell wall. Delayed recovery of locked-in components is triggered by increasing temperature under high moisture content: the rheological analysis of this hygrothermal recovery offers the possibility to gain information on the mechanical conditions during wood formation. After tree felling, the presence of residual stress often causes processing defects during logging and lumbering, thus reducing the final yield of harvested resources. In the
\end{abstract}

Joseph Gril

joseph.gril@umontpellier.fr

$\triangle$ Hiroyuki Yamamoto

hiro@agr.nagoya-u.ac.jp

1 LMGC, University of Montpellier, CNRS, Montpellier, France

2 Graduate School of Bioagricultural Sciences, Nagoya University, Chikusa, Nagoya 464-8601, Japan near future, we expect to develop plantation forests and utilize more wood as industrial resources; in that case, we need to respond to their large growth stress. Thermal treatment is one of the possible countermeasures: green wood heating involves the hygrothermal recovery of viscoelastic locked-in growth strains and tends to counteract the effect of subsequent drying. Methods such as smoke drying of logs are proposed to increase the processing yield at a reasonable cost.

Keywords Mechanical stress - Tension wood . Compression wood $\cdot$ Biomechanics $\cdot$ Hygrothermal recovery

\section{Introduction}

Tree growth stress refers to the mechanical stress permanently supported by wood in a living tree during tree growth. It results from the combined action of two mechanisms, i.e., cell wall maturation and the increase of dead weight [1]. The following scenario is commonly admitted to explain the contribution of maturation-here, the term "maturation" refers to the latest stage of cell wall formation, from the completion of polysaccharides deposition until cell death, and includes lignification. During secondary-wall maturation, the newly differentiated xylem fiber tends to deform in its axial and transverse directions. These dimensional changes are restricted by the alreadyformed xylem. The restraint induces a mechanical stress, or the so-called "maturation stress", at the outermost surface of the secondary xylem, located beneath the layer of differentiating xylem. It provokes, in the older xylem, during each growth increment, a counteractive stress distribution which is superimposed on the pre-existing stress. In 
addition, the increasing tree weight is supported by the older part of the stem (this term is used in this paper in the botanical sense, referring either to trunk or branch). As a result, each stage of growth produces an additional stress distribution balancing the effect of gravity. A complex distribution of mechanical stress, called "growth stress", is thus installed in the living stem. Growth stress does not include, in its definition, the effect of non-permanent loads, such as wind or snow, that impose temporary stress modification only. Growth stress measured at the outermost xylem surface, the "surface growth stress", is more or less the same as the maturation stress.

Due to progressive application of stress on the structure, the growth stress cannot be simply released by the removal of all external mechanical actions. Where gravity suddenly eliminated, the stress distribution would be somewhat modified but not return to zero: most would remain as selfbalanced "residual stress". This is almost the case in a cut $\log$, where the effect of gravity is much reduced as soon as the $\log$ is laid horizontally on the ground.

Growth stress performs essential functions for the tree; it maintains its huge body for a long period against the gravitational force [1]. Reaction wood formation participates in this function, especially when a drastic response is needed. Growth stress becomes extremely high in reaction wood, whereas it is reduced in the opposite side, which causes an upward or downward bending moment in the stem. Thanks to the capacity to control stem orientation, growth stress in reaction wood allows the newly formed xylem to perform a function analogous to that of muscles in animals. Whereas in animals, the muscles would not be effective without bones, in trees, the wood itself fulfills the supporting function of a skeleton. It will be shown in next section that in addition to the "muscular" function, the stress distribution by itself contributes to the "skeletal" function through enhanced bending strength $[2,3]$.

The growth stress is instantaneously released by cutting operations that isolate a small wood portion from the surrounding part of the tree. The resulting strain recovery, or released strain, combined with measurement of material rigidity, permits to evaluate the pre-existing stress. Wood being a viscoelastic material, a delayed recovery is caused. This time-dependent recovery is a temperature-activated process. As will be discussed later, it can be used to gain information on the mechanical conditions of wood at an arbitrary position in the stem during cell wall maturation and subsequent deposition of new wood layers, that is, secondary growth of the stem [4].

The presence of growth stress in tree stems often causes problems when using $\operatorname{logs}$ as raw material for timber products. Examples are radial cracks at the edge of cut logs, crooked sawn lumber, and so forth. When the harvested logs contain reaction wood, processing defects become unpredictably serious and diminish, to a notable degree, the final yield. The resulting economic loss amounts to untold millions of dollars across lumber industry. Wood scientists and engineers are required to find practical solutions to solve those problems.

Thus, the topic of tree growth stress, including that of reaction wood [5], is interesting not only for plant biomechanics and ecophysiology but also in the field of timber engineering. In the present paper, we survey the tree growth stress and related problems, with a special focus on results obtained from our investigations and not all available in journal articles.

\section{Biomechanical functions of growth stress}

\section{Typical growth stress distributions}

In the case of vertically growing and well-balanced trunks, the surface growth stress remains usually more or less constant around the periphery. Axisymmetrical residual stress distributions as displayed in Fig. 1 can then be observed in the felled log. In longitudinal (L) direction, a tensile stress near the periphery is compensated by compression in the center. In transverse directions, the observed pattern is typically radial $(\mathrm{R})$ and tangential ( $\mathrm{T})$ tension in the center; compensated by $\mathrm{T}$ compression near the periphery.

This process could be rationally simulated on the basis of the elastic theory for a polar-anisotropic cylinder [6-12].

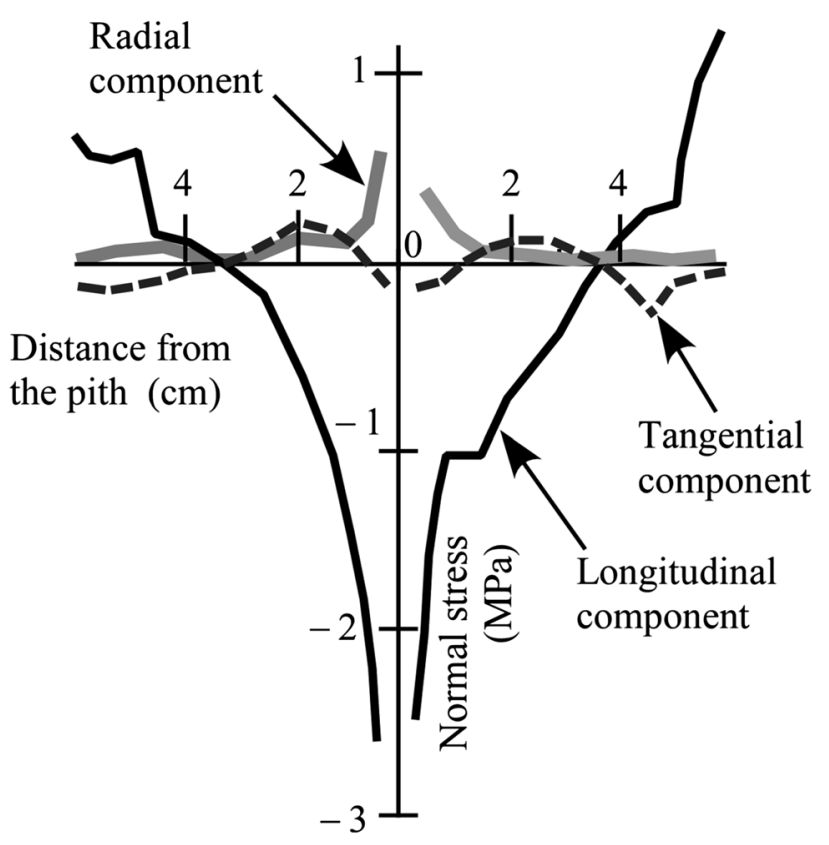

Fig. 1 Residual stress distribution in a well-balanced vertical stem of Populus sp. [6] 
Thanks to the large longitudinal tensile strength of wood, such stress distribution contributes significantly to bending strength of stems. It allows them to sustain much higher wind loading as compared to the case of a stress-free wooden column of similar mechanical properties [3]. It is in this sense that growth stress contributes to the skeletal function of wood in the standing tree [2].

In the case of a tree having an inclined stem or an eccentric secondary growth, an asymmetric surface growth stress is produced, often associated with the production of reaction wood. It results in much more complicated stress distributions in the log.

\section{Reaction wood and biomechanical control of a growing tree}

In an inclined stem, it is needed to counteract the additional bending moment resulting from the production of new wood. In such a stem, the growth stress often differs on two opposite sides of the stem. Such asymmetry can serve not only to maintain stem orientation but also to modify it, aiming either at restoring verticality or searching for light [1]. Here, the growth stress fulfills a "muscular" or "motor" function for the growing stem [2,13].

Exceptional levels of surface growth stress are produced through reaction wood formation. The reaction wood of angiosperms is called "tension wood", because it appears typically along the upper side of an inclined stem (Fig. 2a), where a tensile stress is needed to support the stem against gravity (Fig. 3a). In gymnosperms, reaction wood called "compression wood" is formed along the lower side (Fig. 2b), where a compressive stress is required to support the inclined stem (Fig. 3b). An extremely high tensile maturation stress is generated in tension wood, while a large compressive stress is generated in compression wood (Fig. 3). Thus, the tree shape can be controlled by the generation of abnormal maturation stress generated in reaction wood. Asymmetry in growth, rigidity, and growth stress all contribute to the fine tuning of stem orientation [14-17].

A number of researchers have discussed biomechanical meanings of reaction wood formation, since Archer and Wilson presented a systematic study on the role of abnormal surface growth stress to control the tree shape [18]. A cantilever or curved beam model was used to describe the negative (plagio-) gravitropic behavior of woody plant stems [17, 19-23]. Through simulations of observable shapes of various tree stems, they concluded that, in reaction wood, the surface growth stress is sufficiently large to bend the inclined stem upward against the weeping caused by the increasing weight. It is thus responsible for the negative gravitropic movement of the inclined trunk (Fig. 4). Moreover, the directional angle of the apex (the preferred angle of the elongation zone) plays an important role in controlling the branch shape peculiar to each species. The interaction between surface growth stress and preferred angle in the elongation zone controls stem morphogenesis, for example, the sinusoidal shape of the branch of a weeping kobushi (Magnolia kobus) (Fig. 5a) [22], or that of a maritime pine (Pinus maritima) [20].

\section{Growth stress assessment}

\section{Measuring the surface growth stress}

The surface growth stress can be measured as follows using strain gauges [25-30] (Fig. 6). In a standing tree, the bark,
Fig. 2 Crosscut disks containing typical reaction wood. a Tension wood in a stem of kuri (Castanea crenata) (crescent-shaped band in the light colored zone indicated by an arrow), b Compression wood in a stem of hinoki (Chamaecyparis obtusa) (dark colored zone indicated by an arrow) (Photo H. Yamamoto)
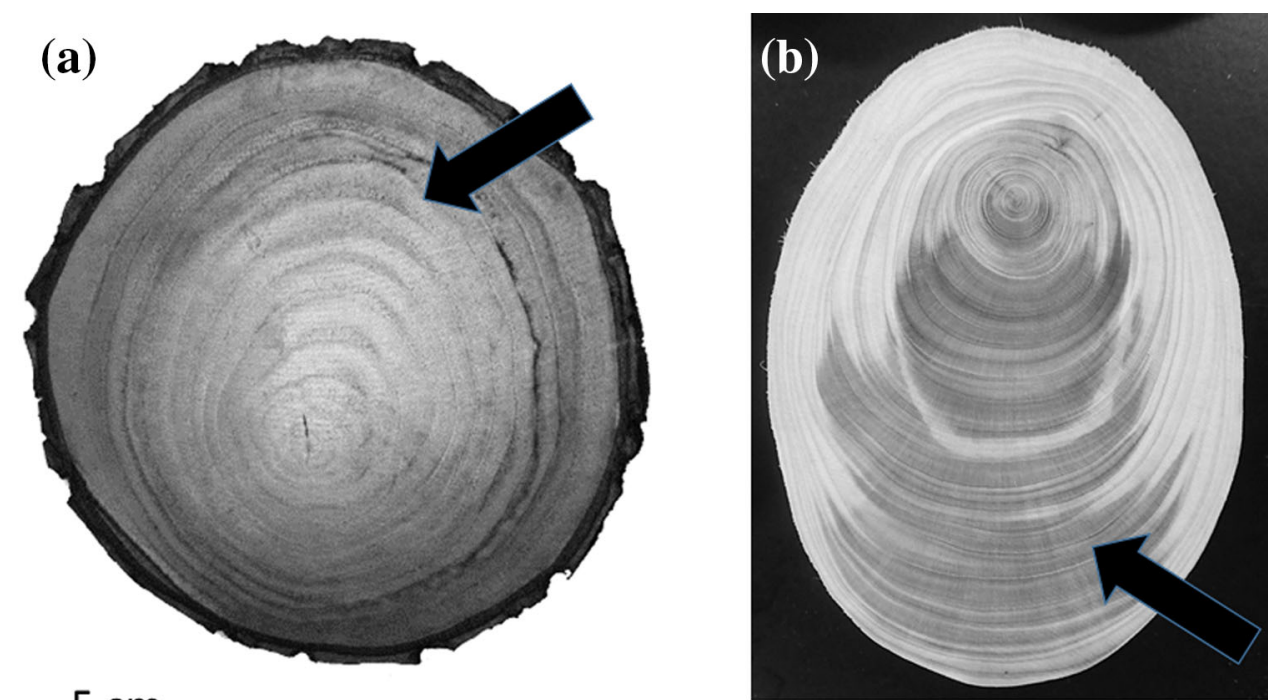
Fig. 3 Reaction wood formation in an inclined stem. a Tension wood (TW) in angiosperm. b Compression wood $(\mathrm{CW})$ in gymnosperm (Illustration H. Yamamoto) (a) Angiosperm

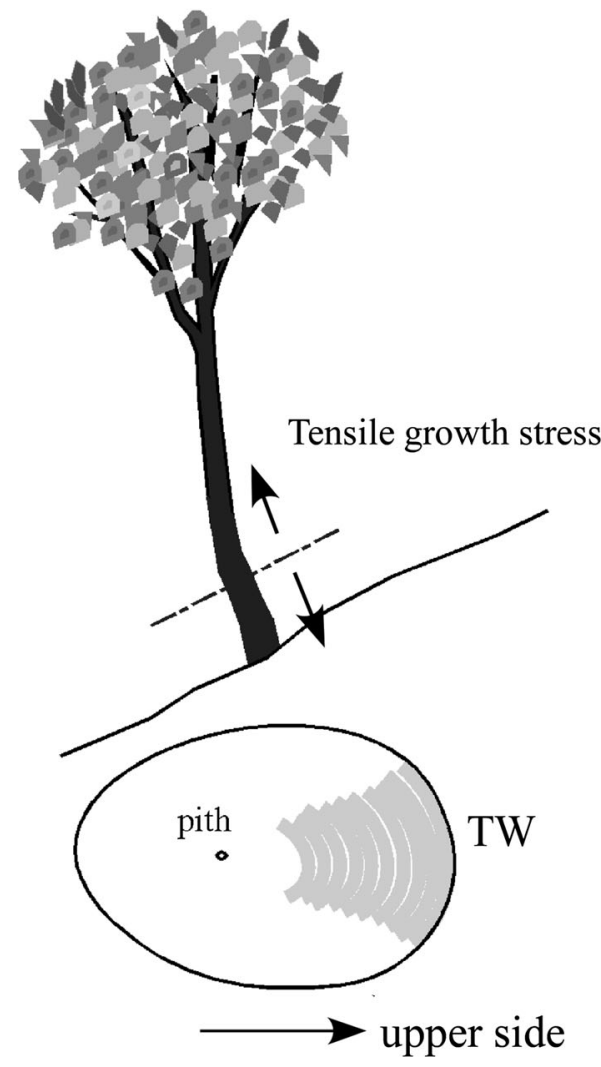

(b) Gymnosperm

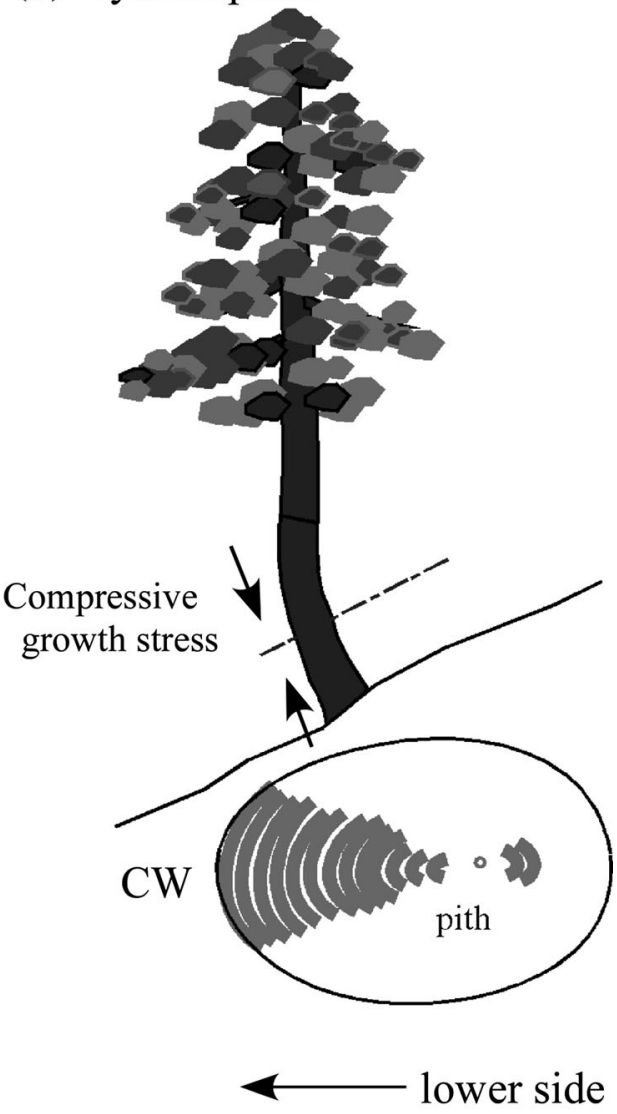

(a)

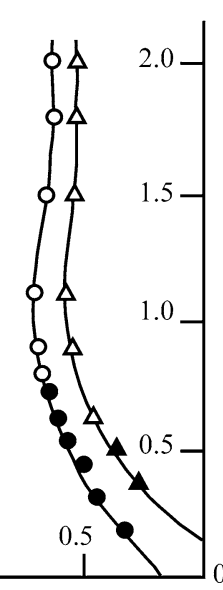

Horizontal distance $(\mathrm{m})$

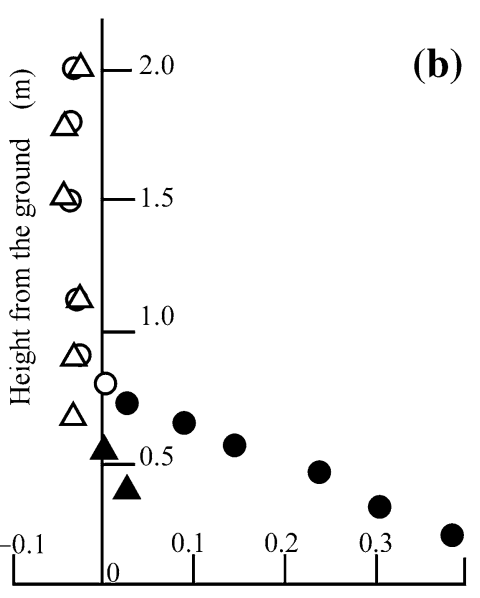

Longitudinal released strain of the surface growth stress (L-strain) (\%)
Fig. 4 Distribution of the longitudinal surface growth stress, evaluated by the released strain with height measurements along the standing tilted stem of an 18-year-old hinoki (Chamaecyparis obtusa). Legends: open circle and open triangle are positions where released contraction was detected. Filled circle and filled triangle are positions where released expansion was detected. Expansion is assigned to compressive stress, contraction to tensile stress [24] phloem, and thin layer of immature xylem at each measuring position are removed, exposing the surface of mature xylem. Thereafter, two electric wire strain gauges are pasted with cyanoacrylate glue in directions parallel and perpendicular to the grain, respectively, and connected to the electric strain meter. Then, the two-dimensional surface stress is released by making grooves of $1-2 \mathrm{~cm}$ in depth on the four sides of strain gauges with a handsaw and a chisel, and the instantaneously released strain components $\alpha_{\mathrm{L}}$ and $\alpha_{\mathrm{T}}$ in longitudinal (L) and tangential (T) directions, respectively, are recorded. In the case of smalldiameter trees, testing conditions (e.g., gauge length or groove depth) may have to be adapted to improve measurement accuracy [31].

After determining the released strains, wood blocks are taken from each measuring position and cut into samples for measuring mechanical properties. If the small restraint caused by bark is neglected, the resulting stress in the outermost layer of the secondary xylem can be considered as essentially two-dimensional in the tangential plane and the surface stress is determined using the following formulas [26]: 

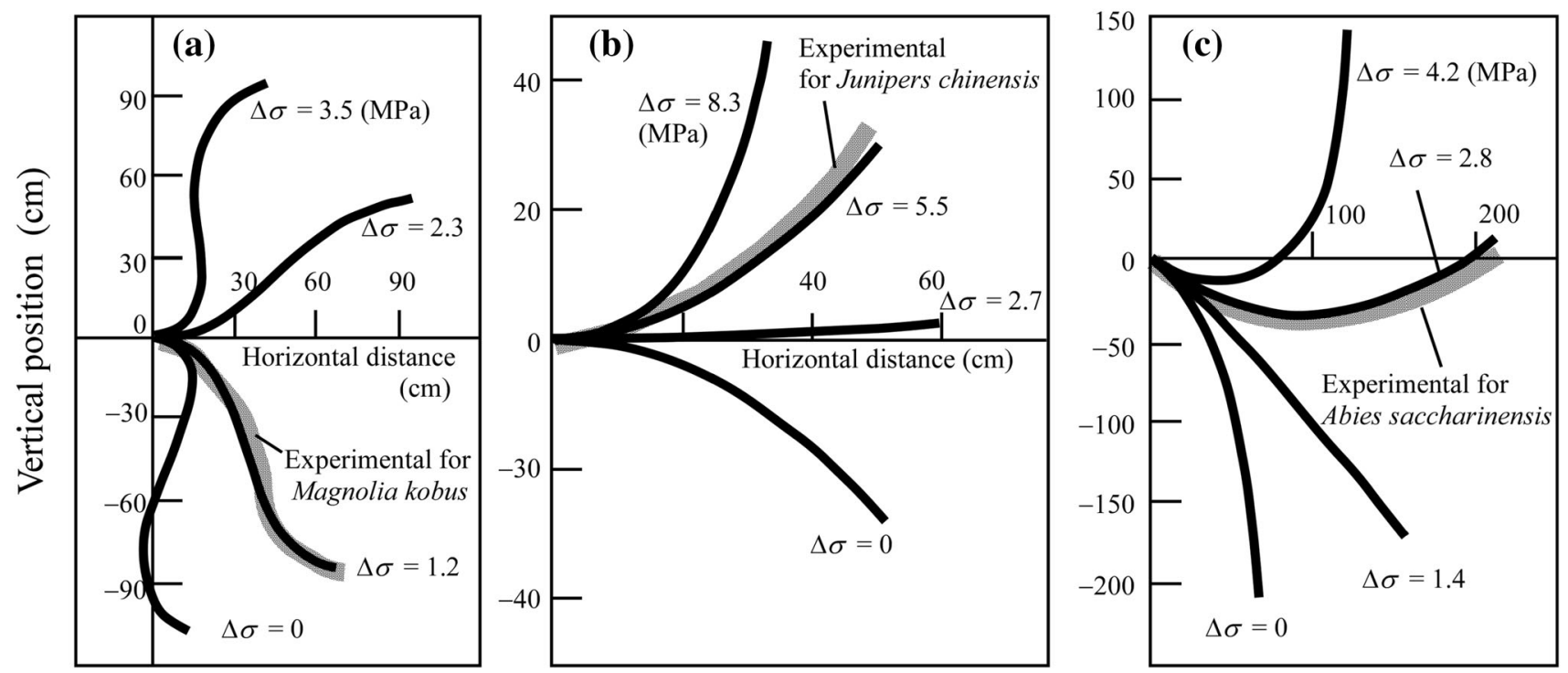

Fig. 5 Examples of simulated patterns of branch shapes after a given growth. $\Delta \sigma$ stands for the assumed value of growth stress difference between the uppermost and the lowermost sides in an inclined stem.

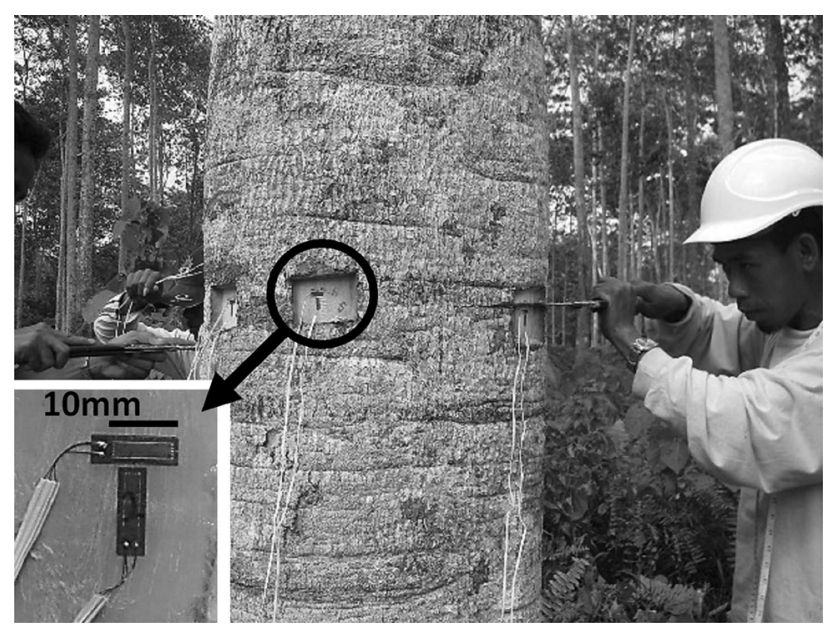

Fig. 6 Measurement of released strains of the surface growth stress using a $10 \mathrm{~mm}$ strain gauge (arrowheaded). At each measuring point, strain gauges are pasted parallel and perpendicular to the grain (Photo H. Yamamoto)

$$
\begin{gathered}
\sigma_{\mathrm{L}}=-\frac{E_{\mathrm{L}}}{1-v_{\mathrm{TL}} v_{\mathrm{LT}}}\left(\alpha_{\mathrm{L}}+v_{\mathrm{TL}} \alpha_{\mathrm{T}}\right), \\
\sigma_{\mathrm{T}}=-\frac{E_{\mathrm{T}}}{1-v_{\mathrm{TL}} v_{\mathrm{LT}}}\left(\alpha_{\mathrm{T}}+v_{\mathrm{LT}} \alpha_{\mathrm{L}}\right)
\end{gathered}
$$

where $E_{\mathrm{L}}$ and $E_{\mathrm{T}}$ are Young's moduli and $v_{\mathrm{LT}}$ and $v_{\mathrm{TL}}$ Poisson's ratios, measured on the samples. We must put a minus sign in front of each equation, because strains $\alpha_{\mathrm{L}}$ and $\alpha_{\mathrm{T}}$ are obtained as released strains of elastic components of residual stress $\sigma_{\mathrm{L}}$ and $\sigma_{\mathrm{T}} . \sigma_{\mathrm{L}}$ and $\sigma_{\mathrm{T}}$ in Eq. (1) are hereinafter referred as "L stress" and "T stress", respectively. In a similar manner, $\alpha_{\mathrm{L}}$ and $\alpha_{\mathrm{T}}$ are, respectively, called " $\mathrm{L}$ strain" and "T strain".
Case a the shoot apex presents a specific directional angle. Cases $\mathbf{b}$ and $\mathbf{c}$ the shoot apex does not present a specific directional angle [22]

Because $v_{\mathrm{TL}} v_{\mathrm{LT}}$ is much smaller than 1 , and $v_{\mathrm{TL}} a_{\mathrm{T}}$ is also small compared to $\mathrm{L}$ strain [32], the first formula of Eq. (1) can be simplified as:

$\sigma_{\mathrm{L}} \approx-E_{\mathrm{L}} \times \alpha_{\mathrm{L}}$.

Peripheral variations of $E_{\mathrm{L}}$ (e.g., the relative difference in elastic modulus between normal and reaction wood) are usually much smaller than those of L strain. Therefore, the value of $\mathrm{L}$ strain can be used as an indicator of $\mathrm{L}$ stress [32]. From Eq. (2), it is reasonable to consider that L stress would be positive (tension) if L strain was negative (contraction). However, it is improper to use the value of $\mathrm{T}$ strain as an indicator of T stress, since $v_{\mathrm{LT}} \alpha_{\mathrm{L}}$ is not exactly smaller than $T$ strain [26]. An indicator of $T$ stress can be obtained by performing the stress-release operations in two steps. Longitudinal (lateral) grooves are made first to release $\mathrm{T}$ stress. Then, the intermediate released strain in the $\mathrm{T}$ direction $\alpha_{\mathrm{T}}^{\prime}$ is recorded. The tangential stress is given as:

$\sigma_{\mathrm{T}}=-E_{\mathrm{T}} \times \alpha_{\mathrm{T}}^{\prime}$

so that $\alpha_{\mathrm{T}}^{\prime}$ can serve as an indicator of $\sigma_{\mathrm{T}}$ [33].

The strain-gauge method is useful for rapidly and precisely determining the local strain. As described below, the fact that the released strain can be related to anatomical properties of the fiber leads to a study on the mechanism of maturation stress occurrence. As an interesting example, Burgert et al. reported that growth stress locally generated in the ray of an oak tree can be measured using strain gauges [25]. Their results indicated that the ray generated tensile growth stress in the $\mathrm{R}$ direction of the trunk (the axial direction of the ray parenchyma cells). 
For a rapid assessment over a large number of trees, alternative techniques such as the "single-hole method" can be used (Fig. 7). It yields a "growth stress indicator" related to the L growth strain by a factor depending on wood anisotropy, characterized by ratios of elastic constants $[1,33,34]$.

\section{Measuring residual stress distributions}

Several methods have been developed to evaluate threedimensional stress distributions within a stem volume (as shown in Fig. 1). They generally require the felling of the tree and the step-by-step destruction of the log. In this destruction process, each cutting operation creates a new free surface allowing a local release of the remaining growth stress. Based on the deformation measured at each cutting step, together with data on mechanical properties of the material, the pre-existing stress can be obtained by back calculation. The differences among the various methods of stress-distribution determination concern mainly the setup of cutting steps and the technique used to measure deformation. When wood is removed from log periphery or from the remaining log, at each stage, the deformation must be measured at the newly created surface, for instance by gluing new strain gauges [6,7]. When it is removed from the inner part of the log, like with the cylinder removal method [8,9], a single set of strain gauges can be used for the whole test. As another approach, the central plank method allows to evaluate, in two steps only, a good approximation of the radial distribution of growth stress along stem diameter $[37,38]$.

(a)
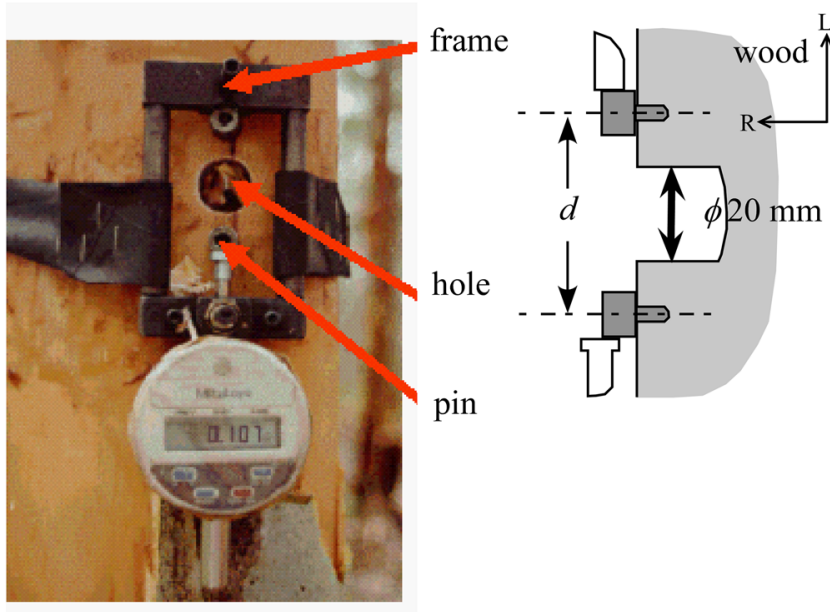

Fig. 7 Example of growth stress assessment performed on a large tree population. a Principle of single-hole method: the change of distance $d$, resulting from the drilling of a central hole, is used as "growth stress indicator" (GSI) [34]. b Relationship between
Growth stress in various wood types as evaluated by released strain data

\section{Normal wood}

Sasaki et al. collected many data of the surface growth stress of 13 domestic Japanese tree species (1 softwood, 12 hardwoods) using the strain-gauge method [26]. They obtained an L stress of $1-10 \mathrm{MPa}$ (3.6 MPa on average), while the $\mathrm{T}$ stress amounted to -0.2 to $-1.0 \mathrm{MPa}$ $(-0.4 \mathrm{MPa}$ on average) in a straight trunk. These values correspond to -0.02 to $-0.10 \%(-0.04 \%$ in average) for the $\mathrm{L}$ strain, and $0.04-0.15 \%$ ( $0.09 \%$ in average) for the $\mathrm{T}$ strain.

\section{Compression wood}

In compression wood, both lignin content and microfibril angle (MFA) in the middle layer of the secondary wall (S2) are larger than in normal wood [24, 39-41]. In contrast to the tensile L stress generated in normal wood, a compressive L stress, expressed by an expansive L strain, is observed in compression wood; it becomes larger with the increase of MFA. The $\mathrm{T}$ strain takes a positive value (expansion) except for the region of very large MFA region where it becomes negative (contraction) (see Fig. 12).

\section{Gelatinous fiber in tension wood}

Many arboreal eudicot angiosperms produce gelatinous fiber (G-fiber) along the upper side of the inclined stem

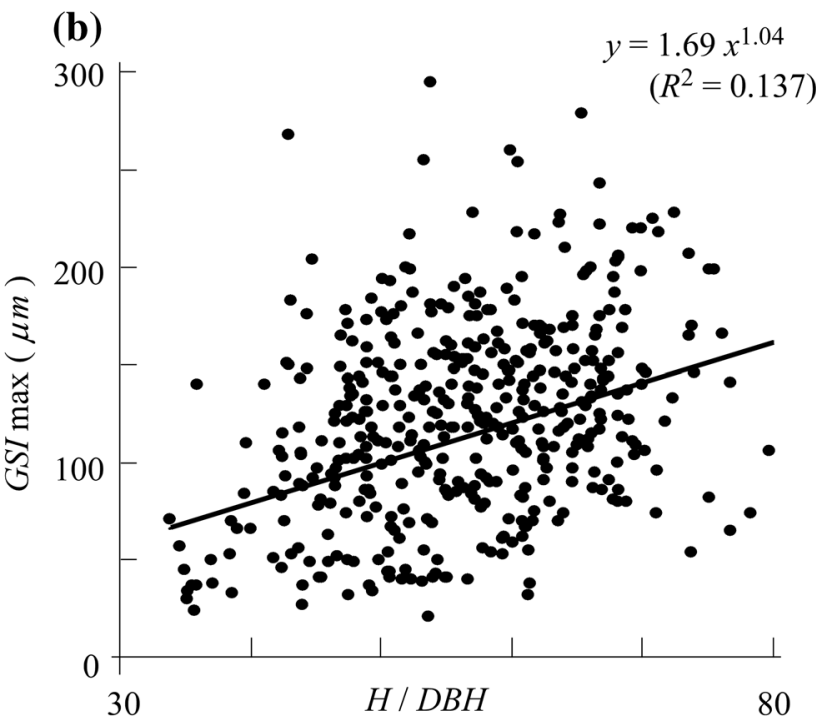

maximum GSI and tree slenderness (height to diameter at breast height ratio, $H / \mathrm{DBH}$ ) for 440 beech trees from 9 stands in 5 European countries $[35,36]$ 

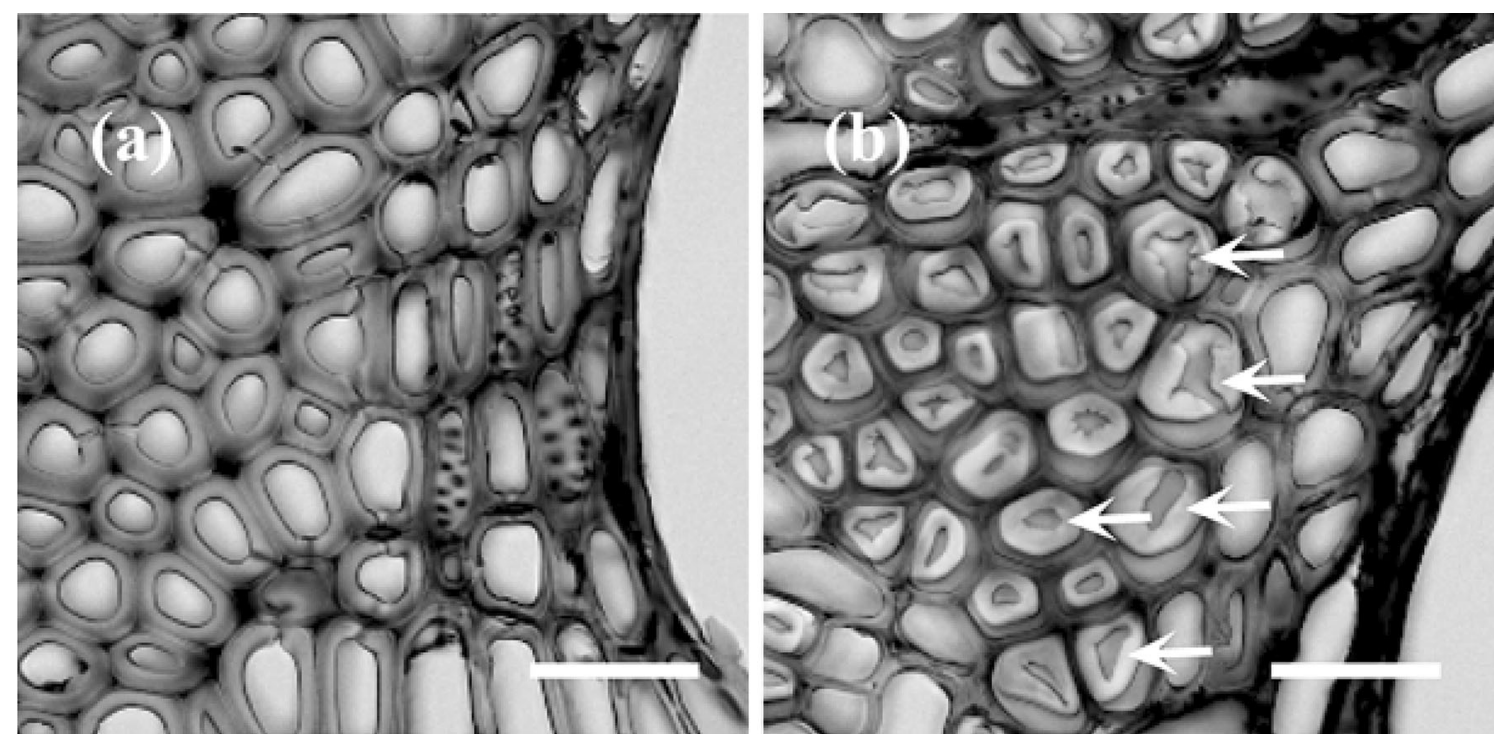

Fig. 8 Microscopic image of a transverse section of a normal wood and $\mathbf{b}$ tension wood of a 75-year-old kunugi (Quercus acutissima) [42]. In tension wood, fibers containing a thick gelatinous layer are formed (arrow headed). The scale are $10 \mu \mathrm{m}$

(Fig. 8). The xylem containing G-fibers can be considered as a type of highly evolved tension wood. The G-fiber has a gelatinous layer (G-layer) as the innermost layer of its cell wall.

The G-layer is very poorly lignified and contains highly crystallized microfibrils, orientated almost parallel to fiber axis [43]. In tension wood, the $\mathrm{L}$ stress possesses a very large value.

Figure 9 shows the peripheral distributions of L strain and area fraction of G-layer in the outermost annual ring at breast height of an inclined stem of a 23-year-old black locust (Robinia pseudoacacia) [44]. The azimuth angle 0

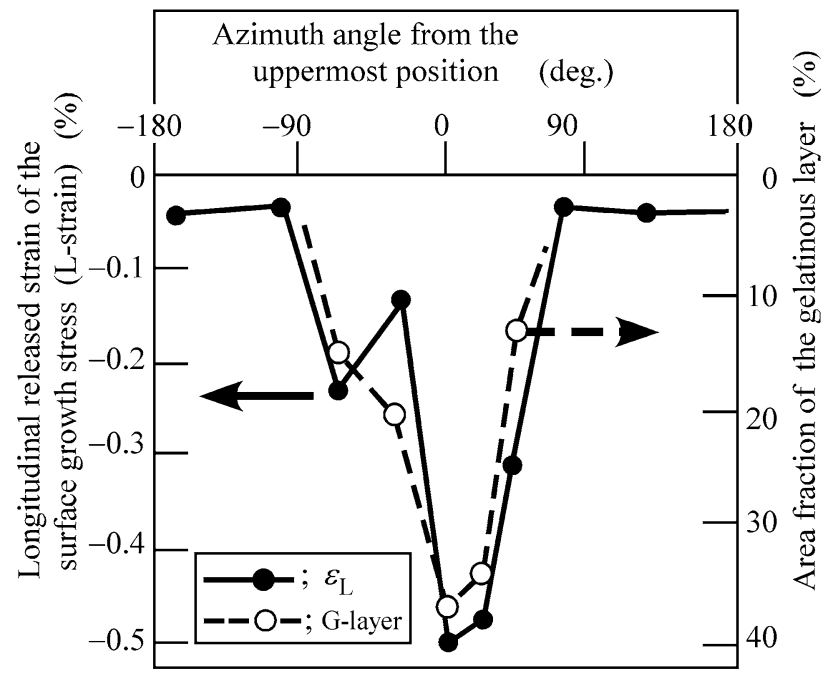

Fig. 9 G-layer fraction and surface growth stress (peripheral distribution) at the breast height of an inclined stem of a 23-year-old Blacklocust (Robinia pseudoacacia) [44] corresponds to the upper side of the inclined stem and the area fraction is calculated as the ratio of total G-layer area divided by wood fiber area (xylem excepting ray, axial parenchyma, and vessel) in a transverse section. As can be seen in Fig. 9, the maximum L strain amounts to $-0.49 \%$ on the upper side, where the area fraction is also the highest. On the other hand, the absolute value of $\mathrm{L}$ strain is small in the lower half side of the stem, where no G-fiber was formed. Similar observations have been made by several authors [45-49]. They suggest that the particular features of G-layer produce a high tensile stress in its axial direction, causing the large tensile L stress of tension wood.

When the G-layer is observed on transverse sections of a water-swollen block using a sliding microtome, it often appears as convoluted in the lumen. Moreover, it is easily peeled off from the lignified secondary wall during sectioning with the microtome. These facts give the impression that the G-layer is attached only loosely to the remainder of the secondary wall, which contradicts its active role in tensile stress generation. However, Clair et al. reported that G-layer detachment, often observed in the microtomed surface of the fresh block, disappears at a distance greater than $100 \mu \mathrm{m}$ from the primary surface of the block that has previously been embedded in resin after being oven dried [50]. From those observations, they concluded that the G-layer was effectively attached to the lignified wall in in-situ conditions, while the observed detachment of the G-layer is a mere artifact of the sectioning, caused by the creation of a free surface and triggered by the cutting process. The tension of the G-layer being balanced by the compression of other layers, the 
creation of free surface results in stress redistribution in its vicinity, which accounts for both the apparent deformation and easy detachment of the G-layer from the lignified wall after the action of sectioning initiated the crack propagation. Based on their findings, we can consider that the characteristic behavior of G-fiber can be, indeed, attributed to the intrinsic property of G-layer [42, 44, 46, 48, 51-56].

\section{Tension wood in Magnoliaceae}

In species belonging to family Magnoliaceae, such as Liriodendron tulipifera, Magnolia obovate, Magnolia Kobus, and so forth, a large tensile L stress is generated on the upper side of an inclined stem where no G-fiber is formed. In the wood of the upper side, the MFA becomes significantly lower, the cellulose content much larger, and the lignin concentration generally lesser compared to the lower side or to a straight stem [47, 48]. Observations using the ultraviolet photomicroscope confirmed that the decrease of lignin concentration in tension wood of Liriodendron tulipifera occurs in the secondary wall of wood fibers from a zone where a large tensile $\mathrm{L}$ stress has been measured (Fig. 10) [57].

In the case of rather primitive angiosperms like Magnoliaceae, large cellulose content and low MFA seem to produce a similar effect as the formation of distinctive G-layer in highly evolved eudicot species [43]. However, the magnitude of tensile L stress in tension wood of those primitive species is somewhat lower than in typical tension wood of highly evolved eudicots species. As typical examples of primitive and evolved types, respectively, the L stress was $20 \mathrm{MPa}$ at most in tension wood of a 51-yearold yellow poplar (Liriodendron tulipifera), equivalent to $-0.15 \%$ of L strain [48], while tension wood of a 23-yearold black locust (Robinia pseudoacacia) generated a tensile $\mathrm{L}$ stress of $70 \mathrm{MPa}$ corresponding to $-0.49 \%$ of $\mathrm{L}$ strain (Fig. 9) [44].

Clair et al. reported that many tropical hardwoods generate an extremely large tensile L stress in their tension wood regardless of the lack of visible G-layer [58]. Simarouba amara (Simaroubaceae) is a typical example of those species [59]. By microscopic observations, Roussel and Clair observed that $S$. amara does produce a G-layer only at a temporary stage of cell wall development; however, it was masked by lignin deposited at a more advanced stage [59]. They call this phenomenon "late lignification". Ruelle et al. reported that, in the tension wood of S. amara, the orientation of cellulose microfibrils is nearly parallel to the fiber axis, and its crystalline size is also significantly higher like in tension wood of Eperia falcataria, a tropical species producing a typical G-layer [60]. With reference to Ruelle et al., Roussel and Clair consider that the mechanism which generates the high tensile stress in tension wood of $S$. amara is likely to be the same as in species showing a typical unlignified G-layer [59]. From observations by Ruelle et al. and Roussel and Clair, it was deduced
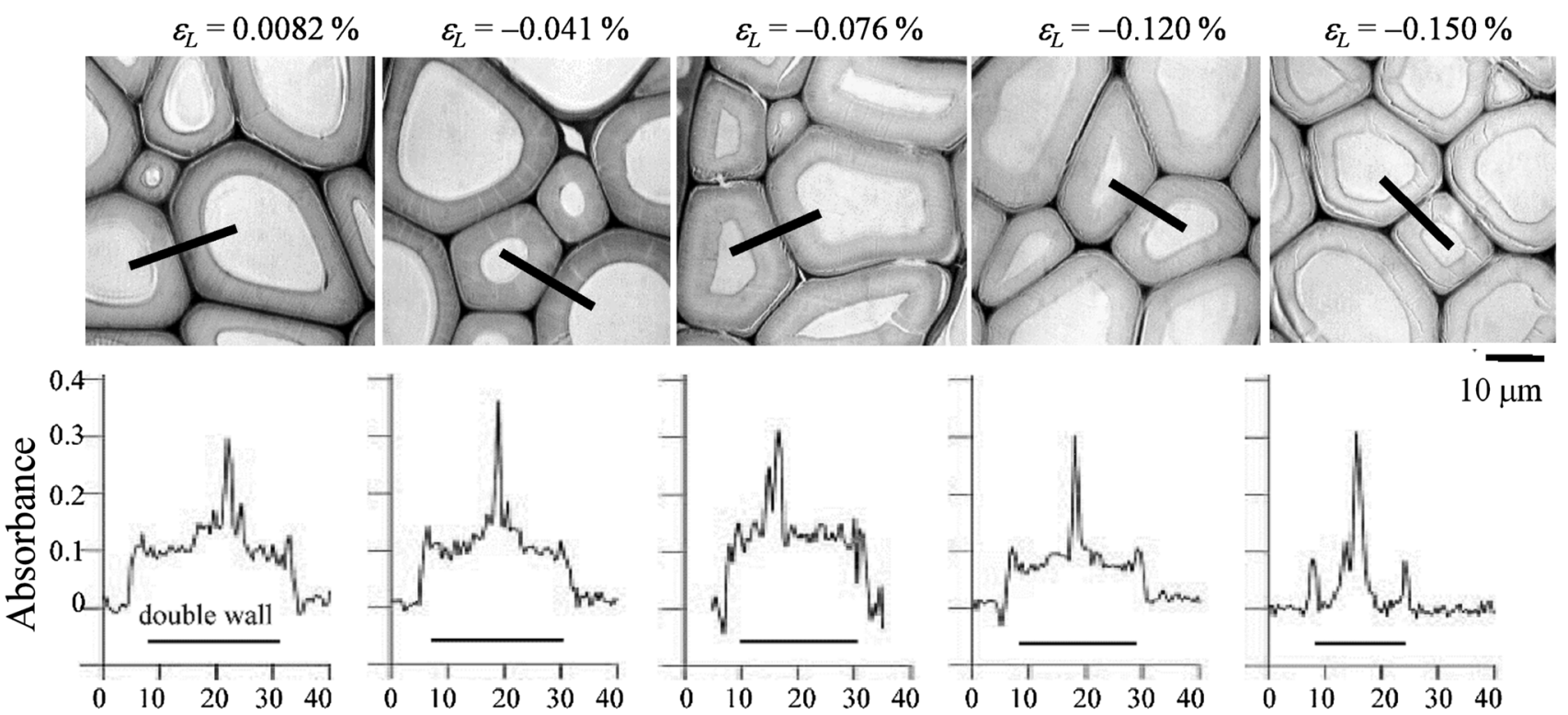

Distance $(\mu \mathrm{m})$

Fig. 10 UV-microscopic image of xylem of a yellow poplar (Liriodendron tulipifera), showing various values of growth strain, and UV absorbance spectra at $270 \mathrm{~nm}$, scanning across the double cell wall. UV absorbance in the secondary wall gradually decreases with an increase of tensile growth stress [57] 
that once a high tensile stress has been generated in the cellulosic network of the G-layer, late lignification does not significantly modify this pre-existing tension $[59,60]$.

\section{The origin of the maturation stress}

Based on numerous experimental observations, Jacobs, who was one of the pioneer scientists in this field, concluded that the maturation stress is generated in the secondary xylem during the secondary growth of trees [61]. This has been well explained in a textbook by Archer [32]. Thereafter, many scientists have tried to elucidate the generation mechanism of maturation stress in xylem fiber walls and proposed various theories for it. For instance, at an early stage, Münch imagined, in the case of tension wood, that the transverse swelling of the G-layer induces the axial contraction of other layers [62]. Two later theories are particularly worth mentioning, the "cellulose-tension hypothesis" and the "lignin-swelling hypothesis". Both assume that the stress originates in a modification of the cell wall material itself during the maturation process.

\section{Two classical theories: cellulose-tension and lignin- swelling hypotheses}

The cellulose-tension hypothesis was proposed by Wardrop, who also studied the formation of G-layer in tension wood and the straightening force in tilted tree [63]. Thereafter, his idea was strongly defended by Bamber as the driving force of stress generation for all wood types [64]. Those authors hypothesized that cellulose microfibrils in the maturing cell walls generate a contractive force in the direction parallel to the molecular chain. The role played by G-layer in tension wood was a strong argument in favor of that hypothesis, this idea being supported by many results $[13,45-49,51-56,65-70]$. No attempt has been made by the supporters of this theory to suggest a detailed molecular mechanism associated with tensioning of cellulose.

The lignin-swelling hypothesis was proposed by Watanabe and Boyd who noted the compressive L-stress generation and high MFA in compression wood [71, 72]. Inspired by Munch's classical idea [62], they presumed that a volumetric increase due to irreversible lignin deposition generates a compressive force in the matrix. In contrast to cellulose-tension hypothesis, some indications of molecular mechanism were suggested. From observations using an ultraviolet photomicroscope, it could be confirmed that the increase in absorbance occurs in the secondary wall of compression wood tracheids [73-76]. Okuyama et al. considered that the accumulation of matrix substance, e.g., lignification, induces the compressive stress in the matrix of maturing cell wall [75]. As a result, the matrix tends to expand in the direction perpendicular to rigid cellulose microfibrils, which forces the compression wood fiber with a high MFA to expand in its axial direction. The origin of a positive $\mathrm{T}$ strain can be explained by the same mechanism. Later, Burgert et al. explained the generation of $\mathrm{L}$ stress over a wide range of MFA using the same idea of expansion perpendicular to rigid cellulose microfibrils [77].

\section{The unified hypothesis}

Wilson pointed out that neither of the above two theories alone seemed adequate to explain the experimental phenomenon over a wide range of MFA, and he suggested that their integration could possibly solve their respective limitations [78]. Afterward, Okuyama and his associates accumulated experimental data that positively demonstrated Wilson's suggestion. They developed a more sophisticated theory, called "unified hypothesis" [79, 80], that incorporated the reinforced matrix mechanism originally proposed by Barber and Meylan [81]. It was later formulated by Yamamoto and coworkers, who applied the reinforced matrix theory to multi-layered cylinders as homogenized models of xylem fibers [82], i.e., softwood tracheid or hardwood normal fiber $(\mathrm{CML}+\mathrm{S} 1+\mathrm{S} 2)$ [83-85], and tension wood's G-fiber (CML + S1 + $\mathrm{S} 2+\mathrm{G}$ ) [86, 87] (Fig. 11). Using these models, they tried to simulate the generation process of anisotropic surface growth stress, based on the idea of the unified hypothesis [83-86]. Their model took into account the kinetics of cell wall maturation with reference to the topo-biochemical process of cell wall formation revealed by Terashima [88]. The curves in Fig. 12 are examples of such trials for

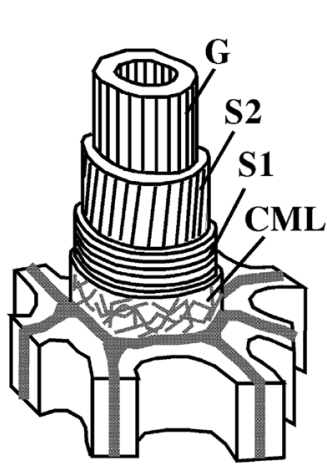

(a)

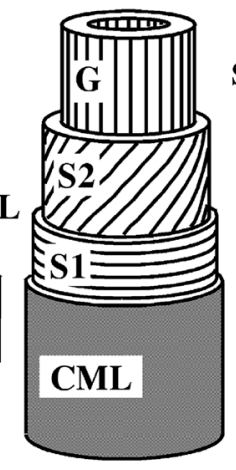

(b)

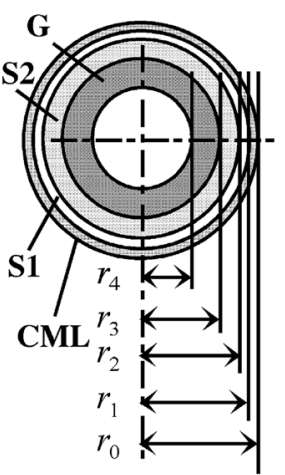

(c)
Fig. 11 Fiber mechanical model to calculate gelatinous fiber (G fiber) deformations [87]. a Structure of the typical tension wood G-fiber. b Multi-layered cylinder model of the G fiber. c Transverse structure of $\mathrm{G}$ fiber cylinder model. In the case of the softwood tracheid and hardwood normal fiber, the model consists of compound middle lamella (CML), outer layer of the secondary wall (S1), and middle layer of the secondary wall (S2) 


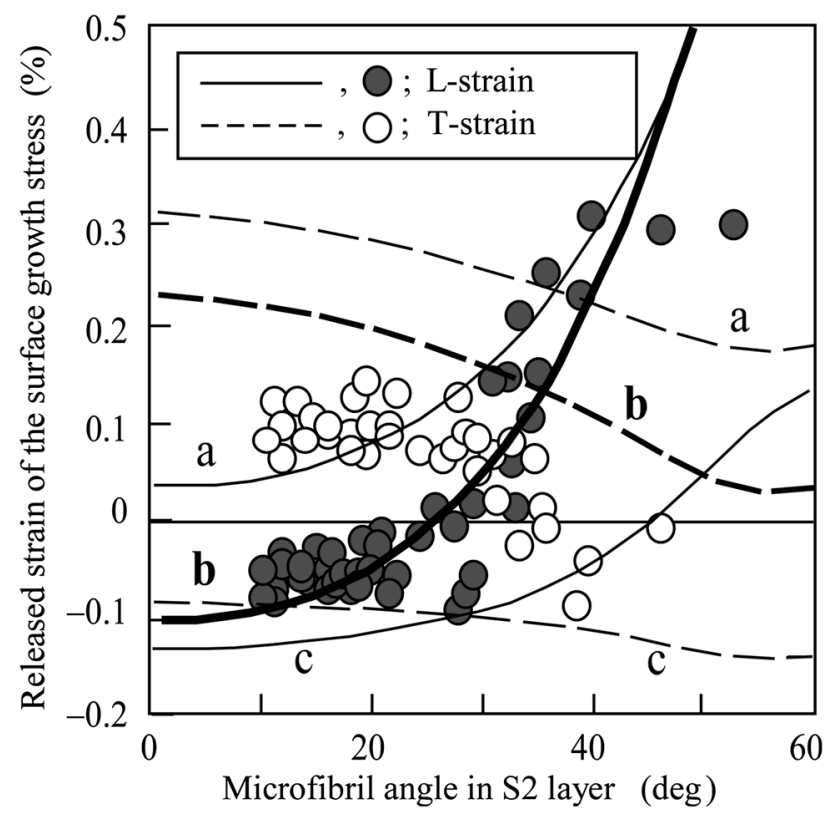

Fig. 12 MFA in S2 layer and growth stress at the breast height of two inclined stems of a 9-year and a 34-year-old sugi (Cryptomeria japonica). Open circle and filled circle correspond to experimental data. The curves correspond to the simulated results under the condition of a lignin-swelling hypothesis, $\mathbf{b}$ unified hypothesis, and c cellulose-tension hypothesis [85]

softwood case. The curves a in Fig. 12 show the results calculated on the basis of lignin-swelling hypothesis. This theory explains the fact that a large positive $\mathrm{L}$ strain is observed in compression wood (CW) with large MFA, while it cannot explain the generation of negative L strain in normal wood with relatively small MFA. The curves b are the result calculated on the basis of cellulose-tension hypothesis. Over a wide range of MFA, both calculated L strain and $\mathrm{T}$ strain become negative, which seriously contradicts the fact that a large positive $\mathrm{L}$ strain is observed in $\mathrm{CW}$ with large MFA, and that the T strain remains positive over a wide range of MFA. The curves $\mathbf{c}$ show the calculated result based on the unified hypothesis, which can explain the observed relationship between the anisotropic surface growth stress and MFA in the S2 layer.

In a similar approach, Gril and his associates also succeeded in describing the variation of maturation stress over a wide range of MFA in S2 layer [89, 90]. In their multilayered model, the maturation process is described by a progressive change of material parameters from an initial to a final value. The simulations show that to account for the observed relationship between MFA and L strain, the model parameters need to be made dependent on MFA or wood type [89].

This unified theory also accounts for the generation of very high tensile $\mathrm{L}$ stress in G-fiber [49, 51, 87]. The unified hypothesis was a consistent theory that explained the growth stress generation not only in normal wood but also in compression wood or tension wood. However, conclusive evidence demonstrating tensile-stress generation in the polysaccharide framework is still confined to few examples [55, 56, 91]. The same can be said for compressive stress in matrix region [91, 92].

Moreover, this hypothesis did not incorporate a precise description of the molecular mechanism involved. As a remark, the "cellulose-tension" may not be understood necessarily as a contraction of the cellulosic crystal itself but as any mechanism leading to the axial contraction of the cellulosic framework; while the "lignin swelling" can refer more generally to any physicochemical process provoking an increase of internal pressure of the amorphous compounds that occupies the space between crystalline parts, presumably induced by an irreversible deposition of lignin-hemicelluloses compound. The unified hypothesis underlines the necessity for both mechanisms to happen during the cell wall maturation process, either simultaneously or in succession. Collaboration between mechanics, anatomy, and biochemistry is necessary to elucidate the generation process of maturation stress in the cell wall and to clarify the exact content of both theories constituting the unified hypothesis.

\section{Recent progress on the tensile-stress generation in tension wood}

Various mechanisms have been proposed in recent years, often focused on the origin of tensile stress in tension wood. Some have considered the role of non-crystalline polysaccharide (NCP) and the related protein, e.g., xyloglucan (XG) and xyloglucan-endotransglycosylase (XET), in G-layer [66, 68, 93, 94], where the joint effect of $\mathrm{XG}$ and XET is hypothesized to induce the tensile-stress generation of G-layer. Others revived the mechanism proposed by Münch with a more sophisticated model [95], which was further integrated with the previous one involving various NCP in G-layer [69, 70]. The assumption of matrix swelling between bridged microfibrils [13, 67], based on observed gel-like features of G-layer [96], was able to explain both the axial contraction and the transverse expansion of G-fibers. All are critically introduced in a recent review of the generation mechanisms of maturation stress [97].

\section{Hygrothermal recovery of growth stress}

\section{The effect of heating green wood}

Many processing defects related to growth stress, such as radial cracks at log ends or distortion of sawn lumber, tend 
to progress with the elapsed time [98-100]. This is because growth stress release is a time-dependent phenomenon, which is easily explained by the viscoelastic nature of wood. In other words, the growth stress consists of two components, elastic and viscoelastic [4, 98, 99, 101]. The creation of a free surface, either due to cutting operations or to crack propagation, is equivalent to an instantaneous recovery, i.e., the release of the elastic component of growth stress. The resulting instantaneous recovery is followed by a delayed recovery caused by rearrangements of cell wall macromolecules, especially those belonging to the amorphous matrix. This interpretation is further confirmed by the amplifying effect of boiling or steaming on observed time-dependent phenomena, which is consistent with viscoelasticity being a thermally activated process. Researchers thus consider the delayed recovery to be caused by the release of viscoelastic components of growth stress [4, 101].

This "hygrothermal recovery" (HTR) is mostly explained by the increase of molecular mobility in green wood through the synergistic effect of lignin softening, which occurs well above $60{ }^{\circ} \mathrm{C}$ in water-saturated conditions [102], and the hydrolytic degradation of hemicelluloses [4, 101, 103]. As a typical order of magnitude, HTR amounts to $+0.2-1.0 \%$ in $\mathrm{T}$ direction, -0.05 to $-0.3 \%$ in $\mathrm{R}$ direction (Fig. 13) and $\pm 0.1 \%$ in L direction [109], although much higher values can be observed in some cases for $\mathrm{L}$ direction, e.g., tension wood [111-113] or compression wood [114-116].

Properly speaking, the analysis of HTR must take into account the progressive accumulation of growth stress during the secondary growth of the stem. The viscoelastic component of growth stress, like the elastic part, depends on the radial position (the distance from the pith). However, there is less radial dependency for HTR than for elastic recovery [100]. To illustrate this, let us compare the case of two pieces of normal wood extracted from the same stem. Wood (A) is taken close to the periphery, so that it has been subjected in recent years to $\mathrm{L}$ tension and $\mathrm{T}$ compression, i.e., surface growth stress. Wood (B) is taken close to the pith, so that it has been subjected to the same $\mathrm{L}$ tension and $\mathrm{T}$ compression a long time ago, but later to $\mathrm{L}$ compression and $\mathrm{T}$ tension as a result of the requirement for mechanical balance in the whole stem section after the secondary growth of the stem. Both (A) and (B) were subjected to the initial stress, $\mathrm{L}$ tension, and $\mathrm{T}$ compression, while they were in the process of cell wall maturation, presumably being under a state of low stiffness and high molecular mobility. With sufficient heating temperature or duration, HTR expresses all components of the locked-in strain. Most of it is the recovery of the viscoelastic component of growth stress locked in wood during the maturation process, more or less the same for (A) and (B) except for differences in growth conditions of juvenile and matured fiber. What happened during the period of time from cell wall formation to tree felling, where most of the differences between (A) and (B) lie, is likely to modify the locked-in viscoelastic components. All this previous loading history contributes, to some degree, to observed HTR, resulting in observed radial variations of HTR (Fig. 14). However, due to the dominance of the initial contribution of maturation stress, radial variations of HTR are much less pronounced than those of instantaneously released strain (or those of growth stress) [109, 117].

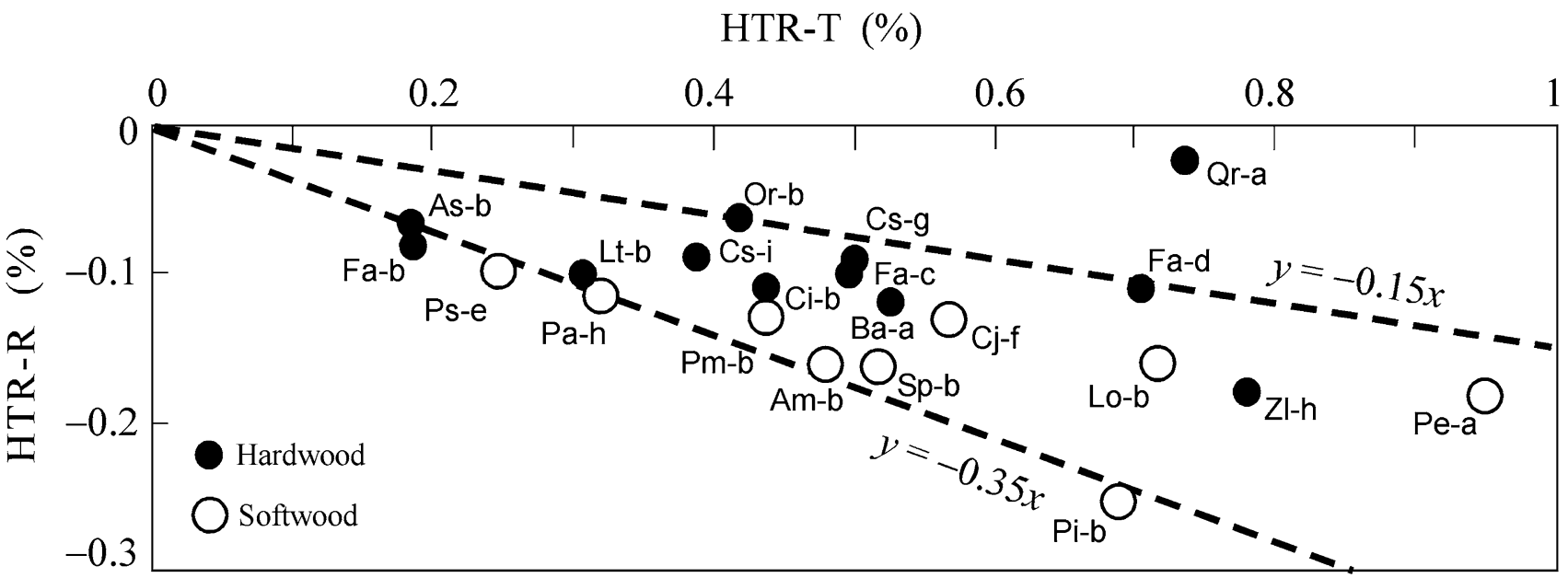

Fig. 13 Hygrothermal recovery (HTR) in R vs T directions, according to various authors. Species: As, Acer saccharinum; Ba, Betula alleghaniensis; Ci, Carya illinoinensis; Cs, Castanea sativa; F, Fagus spp.; Lt, Liriodendron tulipifera; Qr, Quercus rubra; Zl, Ziziphus lotus; Am, Abies magnifica; Cj, Cryptomeria japonica; Lo, Larix occidentalis; P, Pinus spp.; Pa, Picea abies; Pe, Pinus echinata; Pm,
Pseudotsuga menziesii; Ps, Picea sitchensis. Conditions: a $1440 \mathrm{~min}$ at $89-95{ }^{\circ} \mathrm{C}$ [104], b 30-90 min at $99{ }^{\circ} \mathrm{C}$ [105], c $150 \mathrm{~min}$ at $95{ }^{\circ} \mathrm{C}$ [99], d $60 \mathrm{~min}$ at $100{ }^{\circ} \mathrm{C}$ [106], e $330 \mathrm{~min}$ at $80^{\circ} \mathrm{C} \mathrm{[107],} \mathrm{f} 60 \mathrm{~min}$ at $100{ }^{\circ} \mathrm{C}$ [108], g $20 \mathrm{~min}$ at $80{ }^{\circ} \mathrm{C}$ [100], h $75 \mathrm{~min}$ at $80{ }^{\circ} \mathrm{C}$ [109], and i $30 \mathrm{~min}$ at $80{ }^{\circ} \mathrm{C}[110]$ 


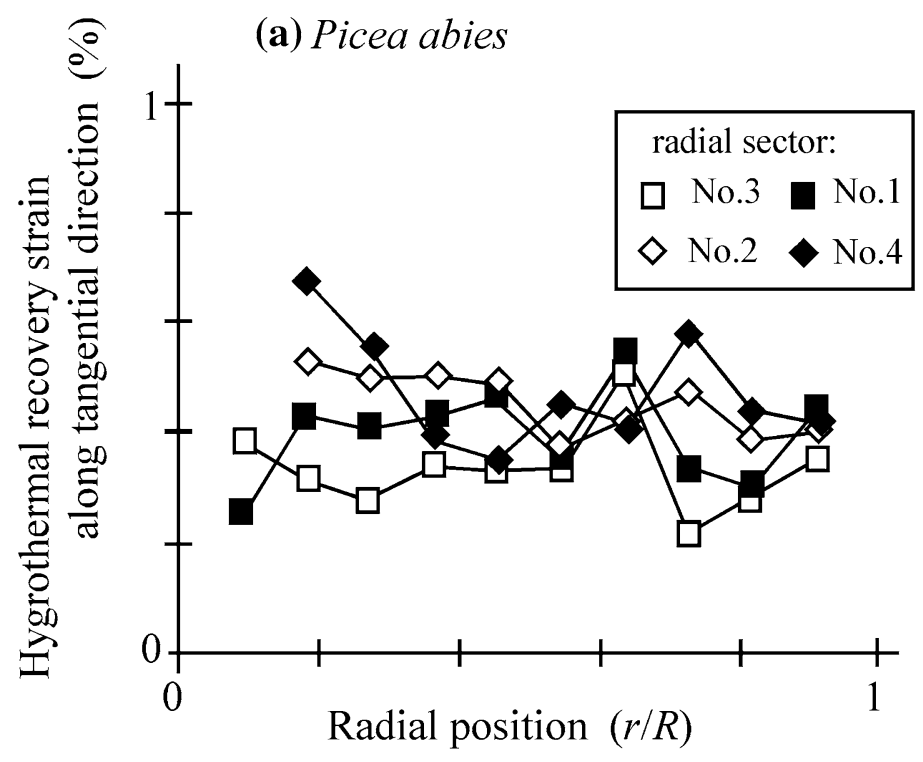

(c)

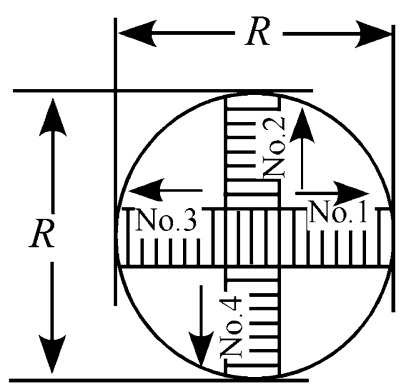

Fig. 14 Radial variation of hygrothermal recovery strain of a Norway spruce (Picea abies) and $\mathbf{b}$ chestnut (Castanea sativa) in $\mathrm{T}$ direction. The deformation was observed on green wood heated from 20 to $80{ }^{\circ} \mathrm{C}$ in $20 \mathrm{~min}$ and maintained in $80{ }^{\circ} \mathrm{C}$ water bath for another 20 min. c Specimen geometry and sampling plan in a log, and d measurement procedure. For chestnut (b), higher values were

\section{Modelling the viscoelastic locked-in growth strains}

The relationship between instantaneous and delayed recovery can be illustrated by the model of Fig. 15. The maturation process of newly formed wood is characterized in $\mathrm{L}$ direction by a progressive process of wood stiffening and fiber contraction (Fig. 15a). For the process to generate a stress, contraction must lag behind stiffening: this is modeled by assuming that contraction occurs suddenly when the material was partially rigidified (Fig. 15b). The total deformation $(\varepsilon)$ of wood under stress $(\sigma)$ in L direction can be schematized as the addition in series of four components (Fig. 15c):

$\varepsilon=\varepsilon^{e}+\varepsilon^{V}+\varepsilon^{W}+\mu$

where $\varepsilon^{e}(=U \sigma)$ is the instantaneous (or short-term) strain, $U$ being the elastic compliance (inverse of modulus of elasticity); $\varepsilon^{V}$ is the medium-term and $\varepsilon^{W}$ is the long-term

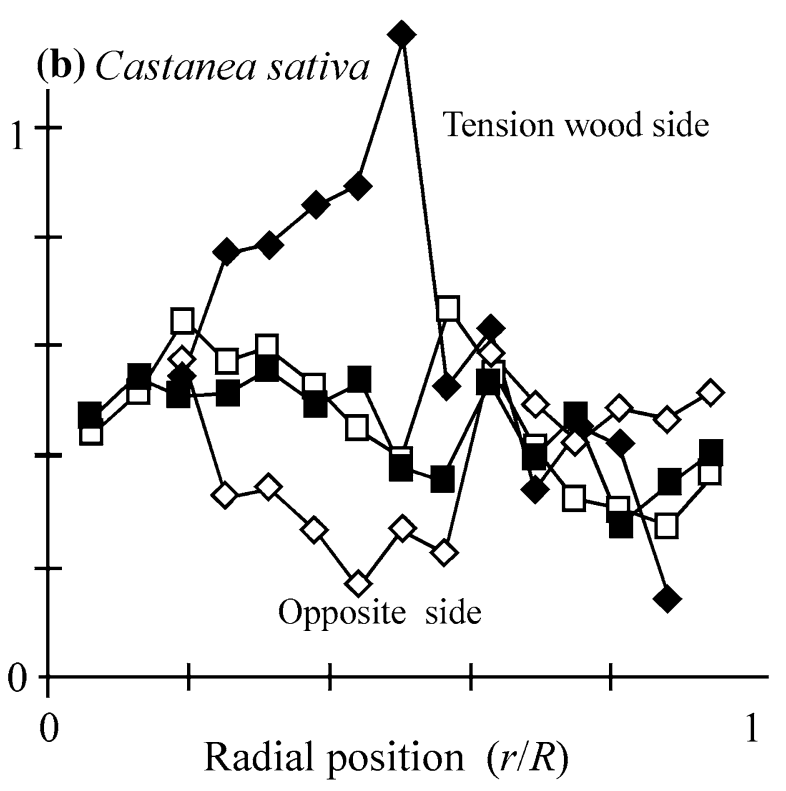

(d)

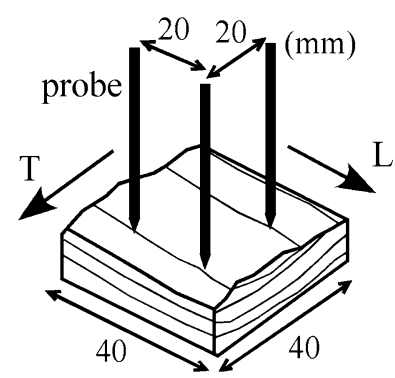

measured in the tension wood side and lower values in the opposite side. Such radial profiles differ radically from those of instantaneous recovery in $\mathrm{T}$ direction, varying from contraction near pith to expansion near periphery, and of much lower magnitude (typically $\pm 0.1 \%$ )(redrawn from [100])

viscoelastic strains; $\mu$ is the strain due to maturation $(\mu<0)$. The evolution of viscoelastic strains is given by the first-order kinetics:

$\frac{\mathrm{d} \varepsilon^{V}}{\mathrm{~d} t}=\frac{V \sigma-\varepsilon^{V}}{\tau^{V}} ; \frac{\mathrm{d} \varepsilon^{W}}{\mathrm{~d} t}=\frac{W \sigma-\varepsilon^{W}}{\tau^{W}}$

where $V$ and $W$ are delayed compliances, while $\tau^{V}$ and $\tau^{W}$ are characteristic times of dashpots, corresponding, respectively, to the medium-term and long-term viscoelastic process. In normal conditions, $\tau^{W} \gg \tau^{V}$ and $\tau^{V}$ is much higher than the times involved in wood formation process. However, during maturation, both $\tau^{V}$ and $\tau^{W}$ are very small, so that $\varepsilon^{V}$ and $\varepsilon^{W}$ reach their respective steadystate limit given by Eq. (5): $\varepsilon^{V}=V \sigma$ and $\varepsilon^{W}=W \sigma$. Consequently, the system was equivalent to a spring of compliance $U+V+W$, resulting in the situation depicted in Fig. $15 \mathrm{~b}$ where the rigidity under maturation is $1 /(U+V+W)$ and the rigidity after maturation is $1 / U$. 
(a)

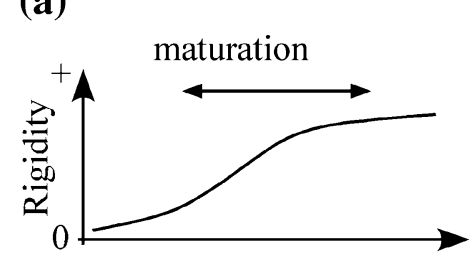

(b)

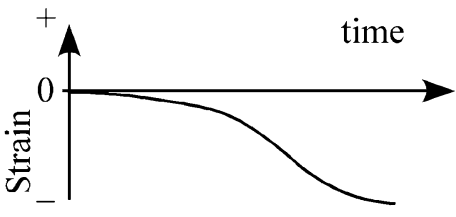

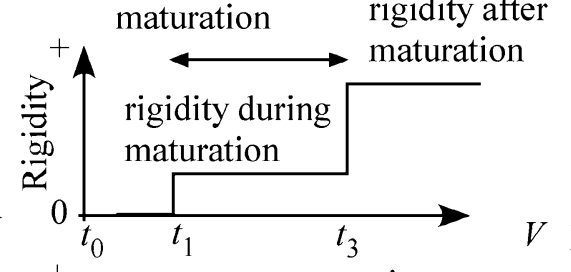

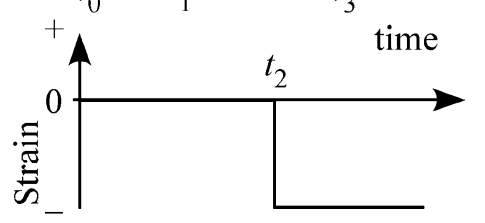

contraction due to maturation (c)

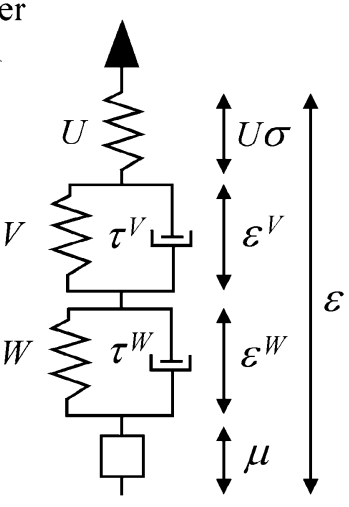

(d)

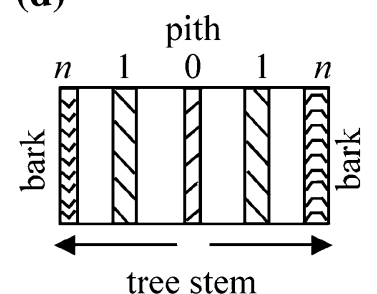

tree stem

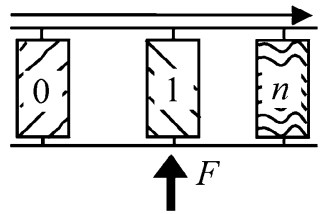

Fig. 15 Rheological interpretation of maturation: a progressive stiffening (the increase of rigidity) and maturation-induced contraction (negative strain), b schematization, c rheological model of an individual wood layer, and d model of axisymmetric growth of a stem. Adapted from [118]

The values of $U, V$, and $W$ depend on the ratio of wood oven-dry density $\left(\rho_{0}\right)$ to cell wall density $\left(\rho_{\mathrm{cw}}\right)$ and on the mean $\operatorname{MFA}(\phi)$ of the cell wall, according to the following relations:

$$
\begin{aligned}
U & =\left(\frac{\rho_{0}}{\rho_{\mathrm{cw}}}\right)\left(u_{0}+u_{1} \tan ^{2} \phi\right) ; V \\
& =\left(\frac{\rho_{0}}{\rho_{\mathrm{cw}}}\right)\left(v_{0}+v_{1} \tan ^{2} \phi\right) ; W=\left(\frac{\rho_{0}}{\rho_{\mathrm{cw}}}\right)\left(w_{0}+w_{1} \tan ^{2} \phi\right)
\end{aligned}
$$

where $u_{0}, u_{1}, v_{0}, v_{1}, w_{0}$, and $w_{1}$ are constants terms, having the unit of a compliance. The maturation strain $\mu$ appearing in Eq. (4) depends on $\phi$ only:

$\mu=\mu_{0} \cos ^{2} \phi+\mu_{1} \sin ^{2} \phi$

where $\mu_{0}$ and $\mu_{1}$ are given constants, homogeneous to a strain. The increasing weight of the tree is supported by an increasing number of wood layers (Fig. 15d). Each wood layer behaves like shown in Fig. 15c as soon as it has been deposited at trunk periphery, which is assumed here to grow in a perfectly balanced way with neither reaction wood sector nor any kind of asymmetry. The increasing load on the cross section at trunk basis is calculated by reducing the tree to a cylinder of specific density 1 , radius $R(t)$, and height $h(t)$.

Figure 16 shows a typical simulation of stem growth. We consider the basal cross section of a 25-year-old tree, with a juvenile wood zone characterized by decreasing MFA and increasing oven-dry density as a function of the radial position, and also support the increasing load of the upper part of the tree. Graphs on the left $(\mathrm{a}-\mathrm{c})$ are spatial distributions of properties and variables (stress and strain components) at given times. Graphs on the right $(\mathrm{d}-\mathrm{g})$ are time evolutions of growth parameters and of stress supported by a wood of given radial positions. Spatial distributions $(\mathrm{a}-\mathrm{c})$ express the mechanical state of the stem, time evolutions $(\mathrm{d}-\mathrm{g})$ the mechanical history of wood in the tree. Wood structural properties, $\tan \phi$ and $\rho_{0}$, are described by Fig. 16c. Tree dimensions are given by Fig. 16g, with $h(t)$ saturating earlier than $R(t)$ and the compressive load on the cross section still increasing at the time of the tree felling $t=25$ (Fig. 16f). Wood located near periphery (e.g., 5-year-old wood, labeled 20 in Fig. 16d) has a short history of tensile loading, while wood close to pith (e.g., 20-year-old wood, labeled 5 in Fig. 16d) was initially under tension, then progressively became compressed and has remained so for the last years. When the tree is finally felled, the observed recovery is expressed by the opposite of strain components: $-\varepsilon^{\mathrm{e}}$ is the elastic recovery, while $-\varepsilon^{V}$ and $-\varepsilon^{W}$ are medium-term recovery and long-term recovery, respectively, that can be triggered by heating green wood. The amount (or duration) of heating required for the expression of $-\varepsilon^{W}$ is likely to be higher than for $-\varepsilon^{V}$. As an example, Fig. 16b predicts that wood cut mid-way between pith and bark (relative radius 0.5 ) would express an elastic recovery of $+0.2 \%$, a lowtemperature (or short-term) recovery of $0.0 \%$, and a hightemperature (or long-term) recovery of $-0.4 \%$. The elastic strain $\varepsilon^{e}$ in Fig. $16 \mathrm{~b}$ is not exactly proportional to the stress at time of tree felling in Fig. 16b, this being due to the lower rigidity of our "juvenile" wood. Thanks to the values chosen for characteristic times in this simulation $\left(\tau^{V}\right.$ smaller than the tree age, $\tau^{W}$ much higher), the long-term recovery expresses mostly the stress acting during wood formation, while the medium-term recovery expresses the mechanical conditions that followed.

A considerable information could be gained on mechanical conditions of wood formation by combining the measurements of (i) HTR for various levels of temperature and of heating duration, (ii) growth stress 

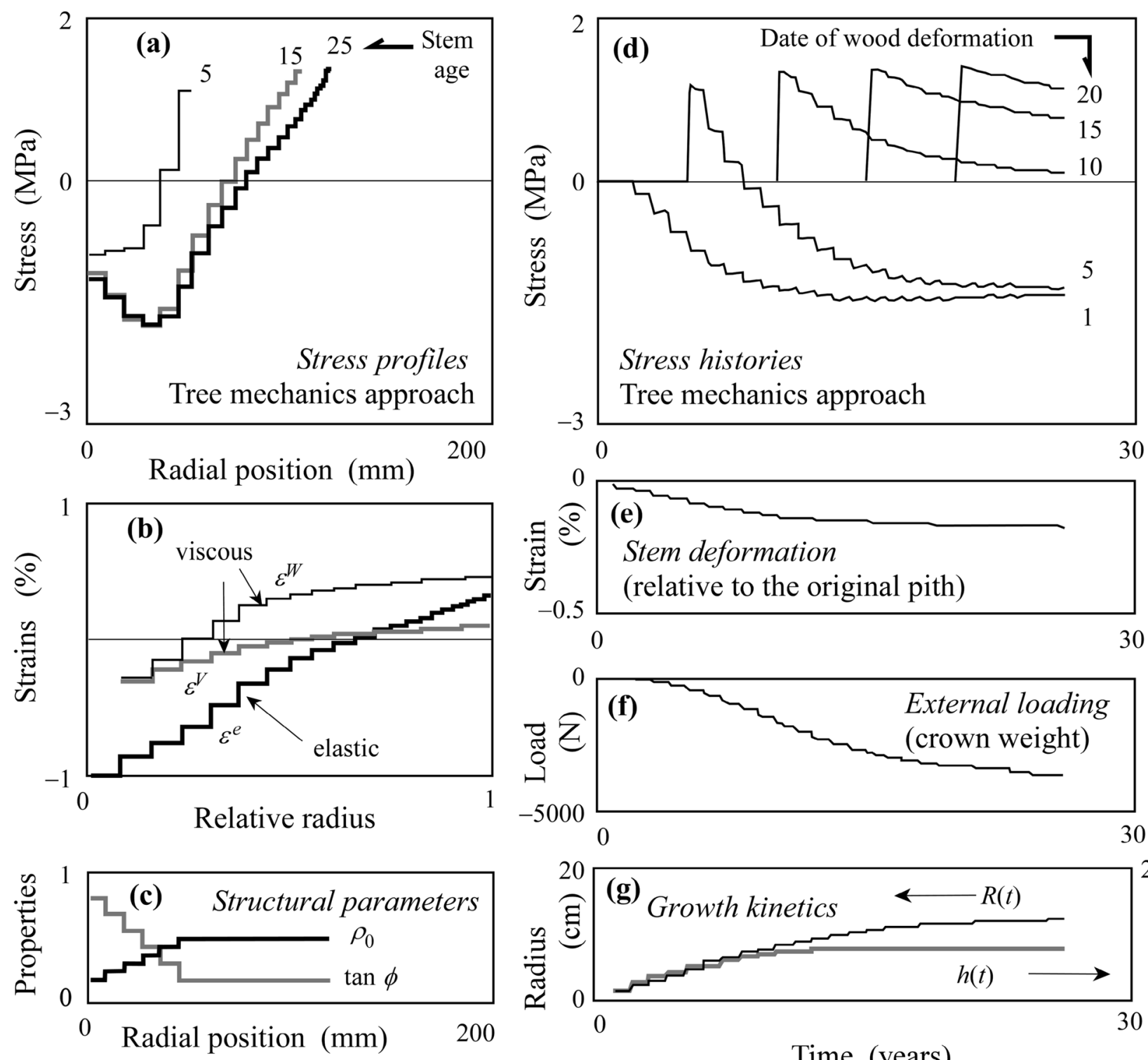

Fig. 16 Simulation of longitudinal stress and strains in an axisymmetrically growing stem. The case of a 25 -year-old tree is considered, with following values for parameters (see Eqs.4-7): compliance (1/ $\mathrm{GPa}): u_{0}=80, v_{0}=20, w_{0}=100, u_{1}=60, v_{1}=40, w_{1}=200$;

distribution within the stem, and (iii) the full viscoelastic spectrum of wood. Consistent data sets providing all required information on a given material are needed for this investigation. They are, unfortunately, not easily available. Sasaki and Okuyama, for instance, measured growth strain and HTR but elastic properties only [108], while others studied the thermally activated multi-process rheological behavior of green wood but without recording growth stress-related data [119-121].

This complexity can be somewhat reduced by focusing on recently made wood, located at stem surface. As explained above, instantaneously released strains at stem

characteristic times (years): $\tau^{V}=10, \tau^{W}=100$; maturation strain: $\mu_{0}=-0.1 \%, \mu_{1}=+0.2 \%$. The juvenile transition has been simulated by a decreasing microfibrillar angle $(\tan \phi)$ and increasing oven-dry density $\left(\rho_{0}\right)$ during the first years of stem growth. Adapted from [118]

surface can be measured on standing tree, as well as components of the elastic tensor of sampled wood, and related to growth stress through Eq. (1). After sampling from the tree, the HTR of the same wood can be measured. It is then possible to combine all these data to obtain information on the mechanical conditions of wood during lignification by assuming that, during the process of lignification, the mechanical behavior was similar to that of green wood heated above glassy transition of lignin. This approach was tried by Gril [122, 123], yielding estimates of an equivalent maturation rigidity tensor and maturation stress calculated according to this hypothesis for a typical 
hardwood and softwood of air-dry specific gravity 0.65 and 0.45, respectively, according to statistical relationships to density provided by Guitard [124]. For the hardwood (res. softwood), the obtained rigidity ratio between mature and maturing wood was 1.4 (1.0) in L direction and 6.0 (5.5) in transverse directions, and the maturation stress was -8 $(-5) \mathrm{MPa}$ in $\mathrm{L}$ direction and $+0.5(+0.3) \mathrm{MPa}$ in transverse directions.

\section{Processing defects}

\section{Growth stress-related defects}

The occurrence of radial cracks at a log end, or lumber crooking (Fig. 17), can be explained in relation to the residual stress distribution inside the log using the beam theory $[125,126]$. The L component of residual stress plays a major role in the observed phenomena. When the log or the trunk is subjected to crosscutting, the wood near log end behaves as if it was subjected to the opposite of the pre-existing growth stress, typically characterized by a peripheral contraction and a central expansion. The resulting bending moment causes radial cracks at log ends, which further develop into end-splitting of the log. The same mechanism explains radial cracks in boards containing the pith or close to it, or the bow-type deformation of green lumber after sawing. The release of transverse components of residual stress often gives an additional contribution in the same direction [110].

As already mentioned, L stress displays very large tensile values in tension wood. Thus, defects at the primary stage of processing often become more serious in a hardwood log containing tension wood, e.g., [127-131]. Now, the source of raw wood in the timber industry is rapidly shifting from natural forest to plantations, mostly constituted of fast-growing hardwood species, e.g., Populus spp.,
Acacia spp., Eucalyptus spp., and so forth; those trees are harvested at a young age to optimize profit. As a result, most of the wood is juvenile. But, in addition, it often contains a high proportion of tension wood associated with the low straightness of the trunk. In view of those current situations, countermeasures must be taken against related processing defects.

Okuyama et al. evidenced a positive relationship between the length of radial crack and surface growth stress in Eucalyptus grandis logs [132]. These data are consistent with the numerical simulations of radial cracks propagation at $\log$ ends by Jullien et al., based on the application of Griffith's theory [128]. According to that theory, the propagation of an existing crack allows the partial release of the elastic energy contained in a body, and the propagation is only possible when that energy release exceeds the amount of energy necessary to extend the crack. The simulations by Jullien et al. explained a number of well-known facts: (i) the increase of cracking risk is often observed in the case of tension wood occurrence; (ii) fewer problems are encountered with softwood species at the crosscutting stage, even in the presence of compression wood; (iii) large-diameter logs tend to crack more than small-diameter logs; and (iv) some species with higher toughness exhibit less cracking defects than others. Other predictions ought to be verified experimentally: number and orientation of cracks in a log containing a reaction wood zone and the increase of cracking risk with wood density [133]. Those investigations contributed to clarifying the direct role of residual stress-resulting from its release-in the occurrence of processing defects such as cracks and deformations. Some techniques, aiming at the reduction of processing defects responsible for the lower yield of harvested resources, will be detailed in the next section. In addition, the presence of reaction wood may cause various problems at the utilization stage because of differences of physical, chemical, and mechanical
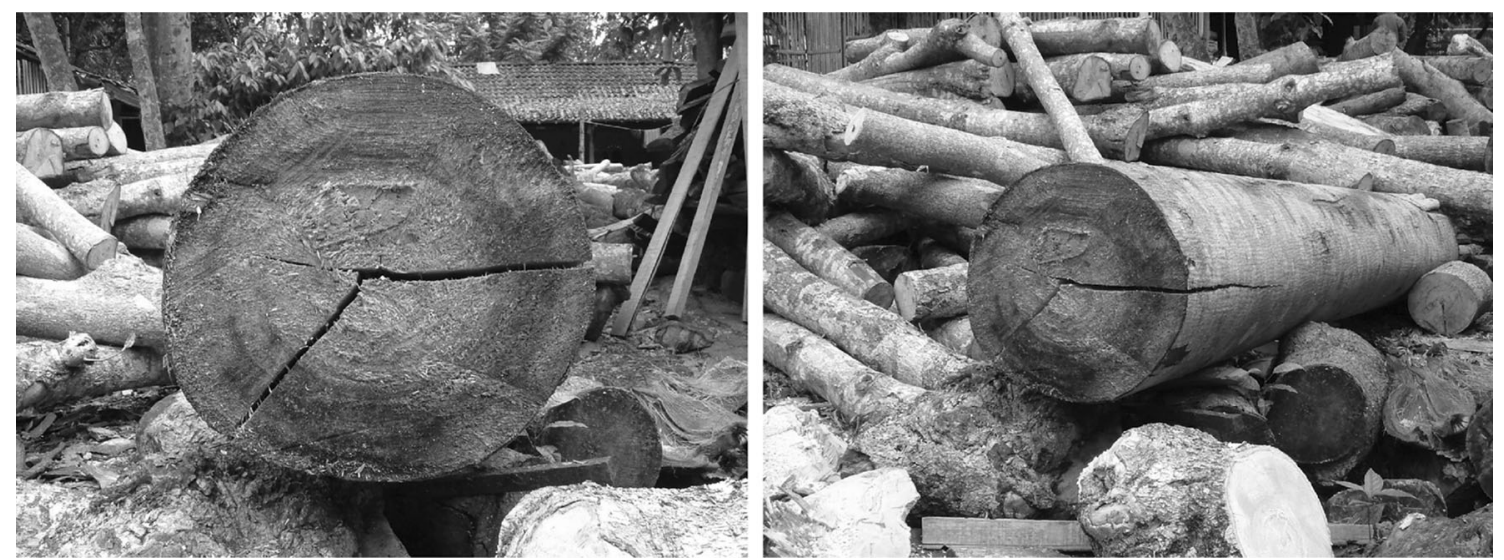

Fig. 17 Occurrence of radial cracks at the log end of Falcataria moluccana, harvested in Java Island, Indonesia (Photo H. Yamamoto) 
properties between reaction wood and normal wood [131]. Such problems do not relate directly to growth stress and are not addressed here.

\section{The control of processing defects}

Residual stress is almost always an annoyance for the timber industry; many scientists and engineers have tried to remove it from green logs. As shown in Fig. 18, HTR shows transverse anisotropy, characterized by tangential expansion $\left(\varepsilon_{\mathrm{T}}>0 ; \varepsilon_{\mathrm{T}}\right.$ stands here for tangential strain) and radial contraction $\left(\varepsilon_{\mathrm{R}}<0 ; \varepsilon_{\mathrm{R}}\right.$ stands for radial strain). Hence, the $\mathrm{T}-\mathrm{R}$ difference becomes positive $\left(\varepsilon_{T}-\varepsilon_{R}>0\right)$. This is opposite to the case of drying shrinkage, where higher $\mathrm{T}$ contraction $\left(\varepsilon_{\mathrm{T}}<\varepsilon_{\mathrm{R}}<0\right)$ results in negative T-R difference $\left(\varepsilon_{\mathrm{T}}-\right.$ $\left.\varepsilon_{\mathrm{R}}<0\right)$. This led some authors to devise a combination of heating and drying schedules to diminish their negative impacts on lumber quality $[4,101,134,135]$ (Fig. 18). Many ideas have been proposed and applied for removing or diminishing the residual stress in logs, e.g., smoking, boiling, and steaming [101]. These heating methods contribute to accelerating the growth stress release through increased molecular mobility of cell wall components. Each has merits and demerits from a cost-effectiveness perspective.

For instance, Okuyama and his associates proposed to reduce residual stress through direct heating by hot smoke

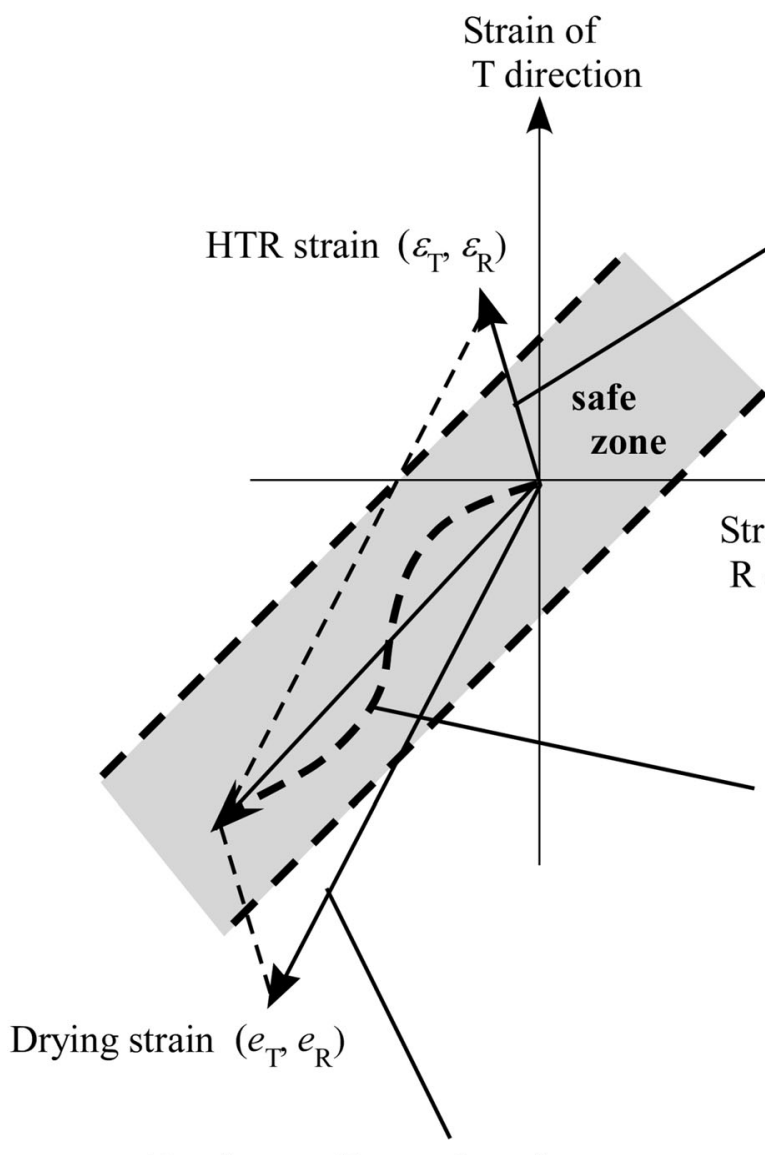

Drying wihtout heating

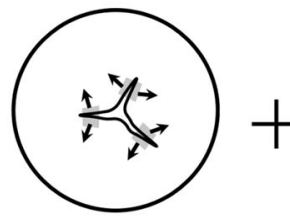

radial heart crack due to logging
A schedule of combination of heating and drying that can avoid additional defects

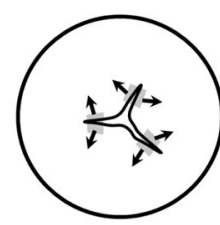

radial heart crack due to logging no additional defects

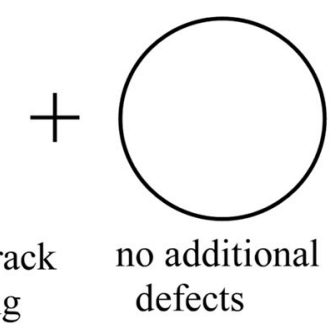

ring shake due to HTR radial heart crack due to logging

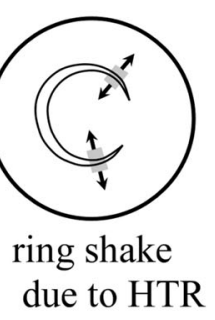

rain of

Fig. 18 Defects due to growth stress-related phenomena in the transverse plane. The combination of drying with heating may reduce the crack risk by maintaining the wood within a safe zone. HTR for hygrothermal recovery (redrawn from [4]) 
Fig. 19 Commercial-scale experiment to assess the effect of direct heat treatment on reduction of residual stresses in $\operatorname{logs}[136]$

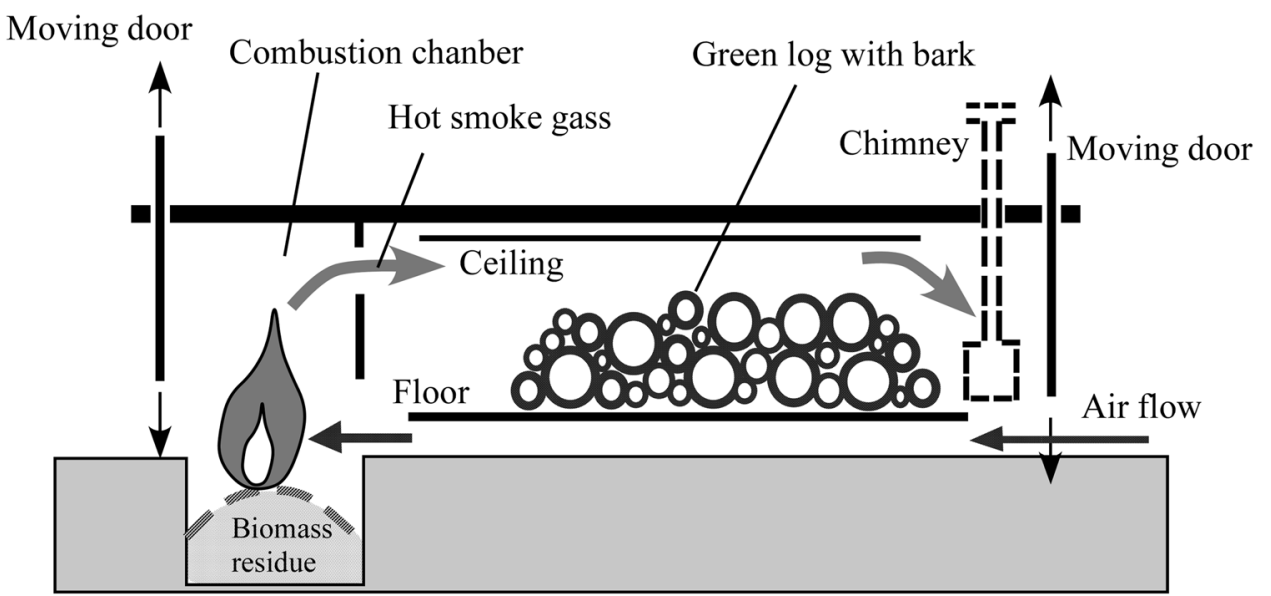

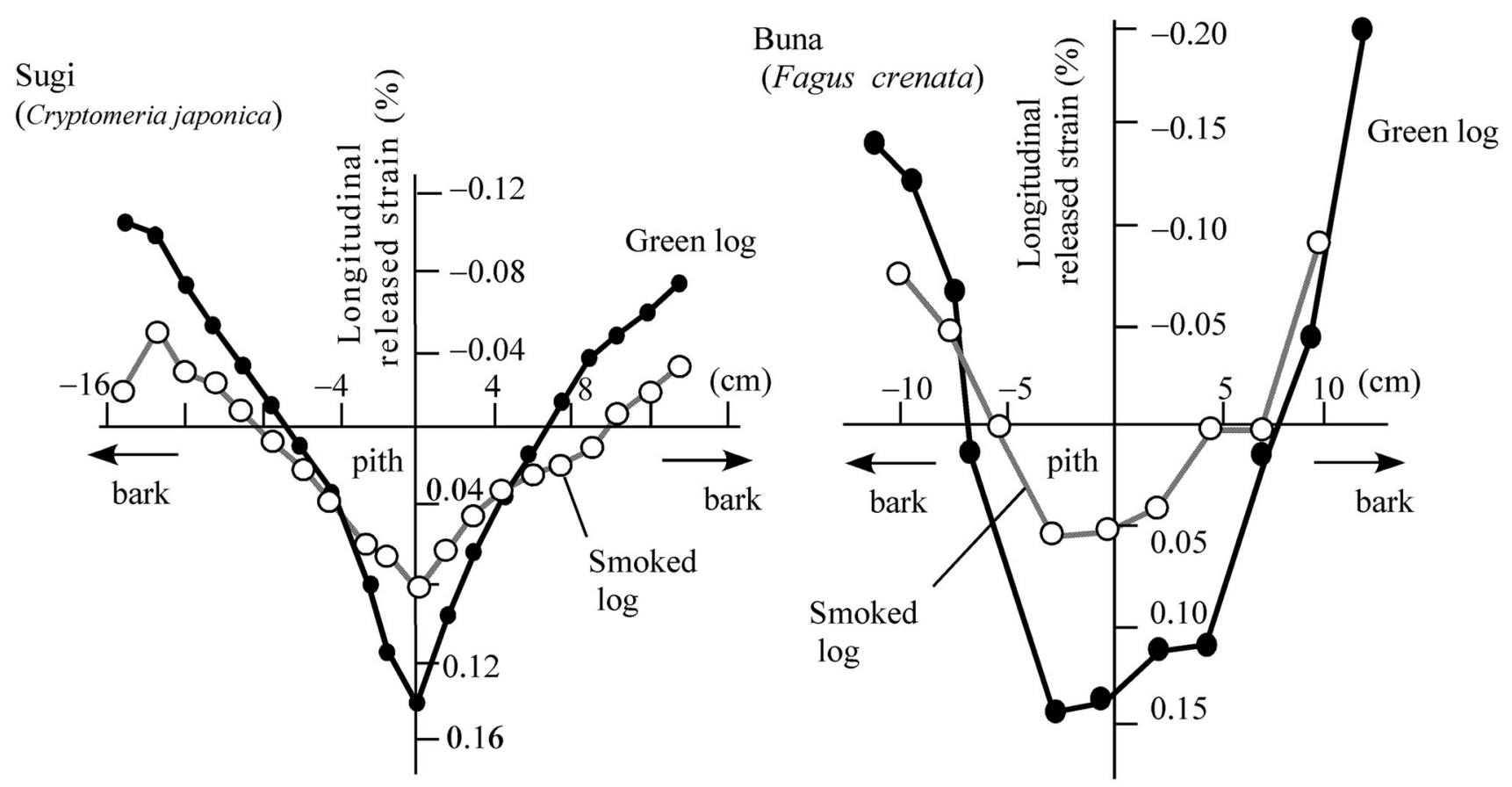

Fig. 20 Change of residual stress in logs due to direct heat treatment. a Sugi (Cryptomeria japonica) [136]; b buna (Fagus crenata) [137]. After $70 \mathrm{~h}$ of heating, the residual stress level is almost halved

[135-138]. This method employs simple and cheap equipment and uses waste wood or sawdust as the heat source (Fig. 19). Therefore, it is comparatively cheap and good for the environment. The optimized treatment time for green logs of sugi (Cryptomeria japonica) and karamatsu (Larix kaempferi) is $30-70 \mathrm{~h}$ using a temperature of more than $100{ }^{\circ} \mathrm{C}$ at $\log$ surface. The condition is about equally effective for hardwood logs containing tension wood, e.g., buna (Fagus crenata) and keyaki (Zelkova serrata). A $40-50 \%$ reduction in residual stress, as evaluated by released strains, can be expected (Figs. 20, 21).

While residual stress is released by heat treatment thanks to the acceleration of viscoelastic response of wood [134-140], log-end crack propagation is also accelerated by the steaming [4]. Consequently, the challenge is to optimize the condition to reduce the residual stress as much as possible while minimizing the secondary loss due to excessive treatment.

\section{Conclusion}

The study of tree growth stress offers technological as much as scientific challenges. From a biomechanical viewpoint, growth stress is essential for tree survival. The study of growth stress generation at cell wall and molecular levels provides us with a number of key knowledge for research, not only to understand the biophysical 

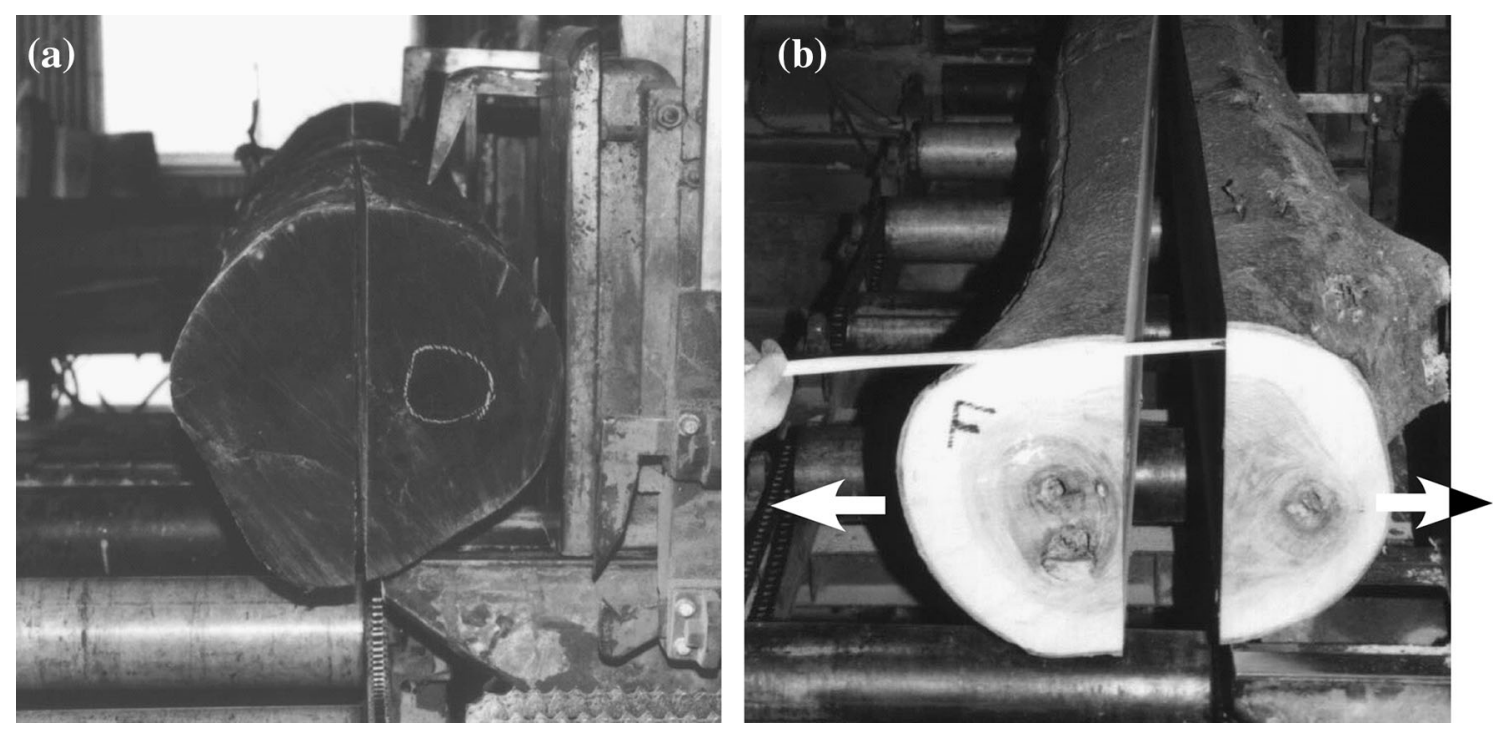

Fig. 21 Reduction of processing defect in logs by direct smoking treatment. Crooking due to sawing is smaller in a a smoked log of buna (Fagus crenata) than in $\mathbf{b}$ a non-treated green log. Arrows in (b) show the crooking of sawn logs using a band saw (Photo by T. Okuyama)

mechanism of cell wall formation but also to develop proper techniques to prevent defects due to growth stress. In the near future, we expect to develop plantation forest and utilize its product as industrial resources: in that case, we need to respond to large growth stress due to reaction wood. Solving the practical problems associated with reaction wood and large growth stress is becoming increasingly important in the future evolution of the wood industry.

Open Access This article is distributed under the terms of the Creative Commons Attribution 4.0 International License (http://crea tivecommons.org/licenses/by/4.0/), which permits unrestricted use, distribution, and reproduction in any medium, provided you give appropriate credit to the original author(s) and the source, provide a link to the Creative Commons license, and indicate if changes were made.

\section{References}

1. Thibaut B, Gril J (2003) Growth stresses. In: Barnett JR, Jeronimidis $\mathrm{G}$ (eds) Wood quality and its biological basis. Blackwell, Oxford, pp 137-156

2. Moulia B, Coutand B, Lenne C (2006) Posture control and skeletal mechanical acclimation in terrestrial plants: implications for mechanical modeling of plant architecture. Am J Bot 93:1477-1489

3. Gordon JE (1978) Structures, or why things don't fall down. Penguin Books, Harmondsworth

4. Gril J, Thibaut B (1994) Tree mechanics and wood mechanics. Relating hygrothermal recovery of green wood to the maturation process. Ann Sci For 51:329-338

5. Gardiner B, Barnett J, Saranpää P, Gril J (2014) The biology of reaction wood. Springer, Berlin

6. Okuyama T, Kikata Y (1975) The residual stress distribution in wood $\log$ s measured by thin layer removal method (in Japanese). J Soc Mater Sci Jpn 24:845-848
7. Doi O, Kataoka K (1967) Determination of principal residual stresses in the anisotropic cylinder (in Japanese). Trans Jpn Soc Mech Eng 33:667-672

8. Sasaki Y, Okuyama T, Kikata Y (1981) Determination of residual stress in a cylinder of inhomogeneous anisotropic material I. Mokuzai Gakkaishi 27:270-276

9. Sasaki Y, Okuyama T, Kikata Y (1981) Determination of residual stress in a cylinder of inhomogeneous anisotropic material II. Mokuzai Gakkaishi 27:277-282

10. Kübler H (1959) Studien über Wachstumsspannungen des Holzes I. Die Ursache der Wachstumsspannungen und die Spannungen quer zur Faserrichtung (in German). Holz Roh-Werk 17:1-9

11. Kübler H (1959) Studien über Wachstumsspannungen des Holzes II. Die Spannungen in Faserrichtung (in German). Holz Roh-Werk 17:44-54

12. Archer RR, Byrnes FE (1974) On the distribution of growth stresses. Part 1: An anisotropic plane strain theory. Wood Sci Technol 8:184-196

13. Fournier M, Alméras T, Clair B, Gril J (2014) Biomechanical action and biological functions. In: Gardiner B, Barnett J, Saranpää P, Gril J (eds) The biology of reaction wood. Springer, Berlin, pp 139-169

14. Yoshida M, Okuyama T, Yamamoto H (1992) Tree forms and internal stresses II: stresses around the base of the branch. Mokuzai Gakkaishi 38:657-662

15. Yoshida M, Okuyama T, Yamamoto H (1992) Tree forms and internal stresses III: growth stresses of branches. Mokuzai Gakkaishi 38:663-668

16. Yoshida M, Okuda T, Okuyama T (2000) Tension wood and growth stress induced by artificial inclination in Liriodendron tulipifera Linn and Prunus spachiana Kitamura f. ascendens Kitamura. Ann For Sci 57:739-746

17. Alméras T, Thibaut B, Gril J (2005) Effect of circumferential heterogeneity of wood maturation strain, modulus of elasticity and radial growth on the regulation of stem orientation in trees. Trees 19:457-467

18. Archer RR, Wilson BF (1970) Mechanics of the compression wood response. I. Preliminary analysis. Plant Physiol 46:550-556

19. O'Reilly OM, Tresierras TM (2011) On the evolution of intrinsic curvature in rod-based models of growth in long slender plant stems. Int J Solids Struct 48:1239-1247 
20. Castéra P, Morlier V (1991) Growth pattern and bending mechanics of branches. Trees 5:232-238

21. Fournier M, Baillères H, Chanson B (1994) Tree biomechanics: growth, cumulative prestresses, and reorientations. Biomimetics 2:229-251

22. Yamamoto H, Yoshida M, Okuyama T (2002) Growth stress controls negative gravitropism in woody plant stems. Planta 216:280-292

23. Fourcaud T, Lac P (2003) Numerical modelling of shape regulation and growth stresses in trees I. An incremental static finite element formulation. Trees 17:23-30

24. Yamamoto H, Okuyama T, Yoshida M, Sugiyama K (1991) Generation process of growth stresses in cell walls. III: growth stress in compression wood. Mokuzai Gakkaishi 37:94-100

25. Burgert I, Okuyama T, Yamamoto H (2003) Generation of radial growth stresses in the big rays of Konara oak trees. J Wood Sci 49:131-134

26. Sasaki Y, Okuyama T, Kikata Y (1978) The evolution process of the growth stress in the tree: the surface stresses on the tree. Mokuzai Gakkaishi 24:149-157

27. Okuyama T, Sasaki Y, Kikata Y, Kawai N (1981) The seasonal change in growth stress in the tree trunk. Mokuzai Gakkaishi 27:351-355

28. Okuyama T, Kawai A, Kikata Y, Sasaki Y (1983) Growth stress and uneven gravitational stimulus in trees containing reaction wood. Mokuzai Gakkaishi 29:190-196

29. Yamamoto H, Okuyama T, Iguchi M (1989) Measurement of growth stresses on the surface of a leaning stem (in Japanese). Mokuzai Gakkaishi 35:595-601

30. Yoshida M, Okuyama T (2002) Techniques for measuring growth stress on the xylem surface using strain and dial gauges. Holzforschung 56:461-467

31. Jullien D, Gril J (2008) Growth strain assessment at the periphery of small-diameter trees using the two-grooves method: influence of operating parameters estimated by numerical simulations. Wood Sci Technol 42:551-565

32. Archer RR (1986) Growth stresses and strains in trees. Springer, New York

33. Clair C, Alteyrac J, Gronvold A, Espejo J, Chanson B, Alméras $\mathrm{T}$ (2013) Patterns of longitudinal and tangential maturation stresses in Eucalyptus nitens plantation trees. Ann For Sci 70:801-811

34. Fournier M, Chanson B, Thibaut B, Guitard D (1994) Measurements of residual growth strains at the stem surface. Observations on different species. Ann Sci For 51:249-266

35. Becker G, Beimgraben T (2001) Occurrence and relevance of growth stresses in Beech (Fagus sylvatica L.) in Central Europe. In: Final report of FAIR-project CT 98-3606. Institut für Forstbenutzung und Forstliche Arbeitwissen-schaft, AlbertLudwigs Universität, Freiburg, p 323

36. Jullien D, Widmann R, Loup C, Thibaut T (2013) Relationship between tree morphology and growth stress in mature European beech stands. Ann For Sci 70:133-142

37. Jacobs RR (1945) The growth stresses of woody stem. Common For Bur Aust Bull 28:1-64

38. Jullien D, Alméras T, Kojima M, Yamamoto H, Cabrolier $\mathrm{P}$ (2009) Evaluation of growth stress profiles in tree trunks: comparison of experimental results to a biomechanical model. Proc Sixth Plant Biomech Conf. Cayenne, GF, pp 16-21

39. Barnett JR, Bonham VA (2004) Cellulose microfibril angle in the cell wall of wood fibres. Biol Rev Camb Philos Soc 79:461-472

40. Shirai T, Yamamoto H, Matsuo M, Inatsugu M, Yoshida M, Sato S, Sujan KC, Suzuki Y, Toyoshima I, Yamashita N (2016) Negative gravitropism of Ginkgo biloba: growth stress and reaction wood formation. Holzforschung 70:267-274
41. Sugiyama K, Okuyama T, Yamamoto H, Yoshida M (1993) Generation process of growth stresses in cell walls. Relation between longitudinal released strain and chemical composition. Wood Sci Technol 27:257-262

42. Yamamoto H, Ruelle J, Arakawa Y, Yoshida M, Clair B, Gril J (2010) Origin of characteristic properties of gelatinous layer in tension wood from Kunugi Oak (Quercus acutissima). Wood Sci Technol 44:149-163

43. Wardrop AB, Dadswell HE (1955) The nature of reaction wood IV: variations in cell wall organization of tension wood fibers. Aust J Bot 3:177-189

44. Yamamoto H, Okuyama T, Yoshida M (1998) Growth stress generation and microfibril angle in reaction wood. In: Butterfield BG (ed) Microfibril angle in wood. International Association of Wood Anatomist, Christchurch, pp 225-239

45. Trenard A, Gueneau P (1975) Relations between growth stresses and tension wood in beech. Holzforschung 29:217-218

46. Okuyama T, Yamamoto H, Iguchi M, Yoshida M (1990) Generation process of growth stresses in cell walls II: growth stress in tension wood. Mokuzai Gakkaishi 36:797-803

47. Yamamoto H, Okuyama T, Sugiyama K, Yoshida M (1992) Generation process of growth stresses in cell walls IV: action of the cellulose microfibril upon the generation of the tensile stresses. Mokuzai Gakkaishi 38:107-113

48. Okuyama T, Yamamoto H, Yoshida M, Hattori Y, Archer RR (1994) Growth stresses in tension wood. Role of microfibrils and lignification. Ann Sci For 51:291-300

49. Yamamoto H, Abe K, Arakawa Y, Okuyama T, Gril J (2005) Role of the gelatinous layer (G-layer) on the origin of the physical properties of the tension wood of Acer sieboldianum. J Wood Sci 51:222-233

50. Clair B, Thibaut B, Sugiyama J (2005) On the detachment of the gelatinous layer in tension wood fiber. J Wood Sci 51:218-221

51. Yamamoto H, Ruelle J, Arakawa,Y, Yoshida M, Clair B, Gril J (2009) Origins of abnormal behaviors of gelatinous layer in tension wood fiber: a micromechanical approach. In: Proceedings of the sixth plant biomechanics conference, Cayenne, pp 297-305

52. Fang C, Clair B, Gril G, Liu S (2008) Growth stresses are highly controlled by the amount of G-layer in poplar tension wood. IAWA J 29:237-246

53. Chang SS, Clair B, Gril J, Yamamoto H, Quignard F (2009) Deformation induced by ethanol substitution in normal and tension wood of chestnut and simarouba. Wood Sci Technol 43:701-712

54. Chang SS, Clair B, Ruelle J, Beauchêne J, Di Renzo F, Quignard F, Zhao GJ, Yamamoto H, Gril J (2009) Mesoporosity as a new parameter for understanding tension stress generation in trees. J Exp Bot 60:3023-3030

55. Clair B, Alméras T, Yamamoto H, Okuyama T, Sugiyama J (2006) Mechanical behavior of cellulose microfibrils in tension wood, in relation with maturation stress generation. Biophys $\mathbf{J}$ 91:1128-1135

56. Clair B, Alméras T, Pilate G, Jullien D, Sugiyama J, Riekel C (2011) Maturation stress generation in poplar tension wood studied by synchrotron radiation microdiffraction. Plant Physiol 155:562-570

57. Yoshida M, Ohta H, Yamamoto H, Okuyama T (2002) Tensile growth stress and lignin content in the cell walls of yellow poplar, Liriodendron tulipifera Linn. Trees 16:457-464

58. Clair B, Ruelle J, Beauchêne J, Prévost MF, Fournier M (2007) Tension wood and opposite wood in 21 tropical rain forest species. 1. Occurence and efficiency of G-layer. IAWA J 27:329-338

59. Roussel JR, Clair B (2015) Evidence of the late lignification of the G-layer in Simarouba tension wood, to assist understanding 
how non-G-layer species produce tensile stress. Tree Physiol 35:1366-1377

60. Ruelle J, Yamamoto H, Thibaut B (2007) Growth stresses and cellulose structural parameters in tension and normal wood from three tropical rainforest angiosperm species. Bioresources 2:235-251

61. Jacobs MR (1938) The fibre tension of woody stems with special reference to the genus eucalyptus. Commonw For Bur Aust Bull 22:1-39

62. Munch E (1938) Statik und Dynamik des Schraubigen Baus der Zwellwand, besonders der Druk- und Zugholzes (in German). Flora 32:357-424

63. Wardrop AB (1965) The formation and function of reaction wood. In: Cote WA Jr (ed) Cellular structure of woody plants. Syracuse University Press, New York, pp 373-390

64. Bamber RK (1978) The origin of growth stresses. In: Contributed paper. IUFRO conference, Philippines, pp 1-7

65. Clair B, Ruelle J, Thibaut B (2003) Relationship between growth stress, mechanical-physical properties and proportion of fibre with gelatinous layer in chestnut (Castanea sativa Mill.). Holzforschung 57:189-195

66. Mellerowicz EJ, Immerzeer P, Hayashi T (2008) Xyloglucan: the molecular muscle of trees. Ann Bot 102:659-665

67. Alméras T, Clair B, Gril J (2009) The origin of maturation stress in tension wood: using a wide range of observations to assess hypothetic mechanistic models. In: Hofstetter K (ed) COST FP0802 workshop on experimental and computational methods in wood micromechanics. COST FP0802 workshop, Vienna, pp 105-106

68. Hayashi T, Kaida R, Kaku T, Baba K (2010) Loosening xyloglucan prevents tensile stress in tree stem bending but accelerates the enzymatic degradation of cellulose. Russ J Plant Physiol 57:316-320

69. Mellerowicz EJ, Gorshkova TA (2012) Tensional stress generation in gelatinous fibres: a review and possible mechanism based on cell wall structure and composition. J Exp Bot 63:551-565

70. Gorshkova T, Mokshina N, Chernova T, Ibragimova N, Salnikov V, Mikshina $\mathrm{P}$, Tryfona $\mathrm{T}$, Banasiak A, Immerzeel $\mathrm{P}$, Dupree P, Mellerowicz EJ (2015) Aspen tension wood fibers contain beta- $(1 \rightarrow 4)$-galactans and acidic arabinogalactans retained by cellulose microfibrils in gelatinous walls. Plant Physiol 169:2048-2063

71. Watanabe H (1965) A study of the origin of longitudinal growth stresses in tree stems. Proceedings of the IUFRO congress. IUFRO, Melbourne, pp 1-17

72. Boyd JD (1972) Tree growth stresses. V. Evidence of an origin in differentiation and lignification. Wood Sci Technol 6:251-262

73. Wood JR, Goring DAI (1971) The distribution of lignin in stem wood and branch wood of Douglas fir. Pulp Pap Mag Can 72:T95-T102

74. Fujita M, Saiki H, Harada H (1978) The secondary wall formation of compression wood tracheids II. Cell wall thickening and lignification. Mokuzai Gakkaishi 24:158-163

75. Okuyama T, Takeda H, Yamamoto H, Yoshida M (1998) Relation between growth stress and lignin concentration in the cell wall. Ultraviolet microscopic spectral analysis. J Wood Sci 44:83-89

76. Hiraide H, Yoshida M, Ihara K, Sato S, Yamamoto H (2014) High lignin deposition on the outer region of the secondary wall middle layer in compression wood matches the expression of a laccase gene in Chamaecyparis obtusa. J Plant Biol Res 3:87-100

77. Burgert I, Eder M, Gierlinger N, Fratzl P (2007) Tensile and compressive stresses in tracheids are induced by swelling based on geometrical constraints of the wood cell. Planta 226:981-987
78. Wilson BF (1981) The development of growth strains and stresses in reaction wood. In: Barnet JR (ed) Xylem cell development. Castel House, Turnbridge Wells, pp 255-290

79. Okuyama T, Kawai A, Kikata Y, Yamamoto H (1986) The growth stresses in reaction wood. In: Proceedings of the XVIII IUFRO world congress, Yugoslavia, pp 249-260

80. Yamamoto H, Okuyama T (1988) Analysis of the generation process of growth stresses in cell walls (in Japanese). Mokuzai Gakkaishi 34:788-793

81. Barber NF, Meylan BA (1964) The anisotropic shrinkage of wood. A theoretical model. Holzforschung 18:146-156

82. Yamamoto H, Almeras T (2007) Mathematical verification of reinforced-matrix hypothesis by Mori-Tanaka theory. J Wood Sci 53:505-509

83. Yamamoto H, Okuyama T, Yoshida M (1994) Micromechanics of growth stress generation in wood cell wall. In: Proceedings of the fourth international conference on residual stress, Baltimore, pp 870-878

84. Yamamoto H, Okuyama T, Yoshida M (1995) Generation process of growth stresses in cell walls VI. Analysis of the growth stress generation by using a cell model having three layers (S1, S2, and I + P). Mokuzai Gakkaishi 41:1-8

85. Yamamoto H (1998) Generation mechanism of growth stresses in wood cell walls: roles of lignin deposition and cellulose microfibril during cell wall maturation. Wood Sci Technol 32:171-182

86. Yamamoto H, Okuyama T, Yoshida M (1993) Generation process of growth stresses in cell walls. V. Model of tensile stress generation in gelatinous fibers. Mokuzai Gakkaishi 39:118-125

87. Yamamoto H (2004) Role of the gelatinous layer on the origin of the physical properties of the tension wood. J Wood Sci 50:197-208

88. Terashima N (1990) A new mechanism for formation of a structurally ordered protolignin macromolecule in the cell wall of tree xylem. J Pulp Pap Sci 16:J150-J155

89. Gril J, Sassus F, Yamamoto H, Guitard D (1999) Maturation and drying strain of wood in longitudinal direction: a single-fiber mechanical model. In: Proceedings of the third workshop on connection between silviculture and wood quality through modelling approaches and simulation software, La Londe-LesMaures, pp 309-314

90. Alméras T, Gril J, Yamamoto H (2005) Modelling anisotropic maturation strains in wood in relation with fibre boundary conditions, microstructure and maturation kinetics. Holzforschung 59:347-353

91. Toba K, Yamamoto H, Yoshida M (2013) Micromechanical detection of growth stress in wood cell wall by wide angle X-ray diffraction (WAX). Holzforschung 67:315-323

92. Abe K, Yamamoto H (2006) Change in mechanical interaction between cellulose microfibril and matrix substance in wood cell wall induced by hygrothermal treatment. J Wood Sci 52:107-110

93. Nishikubo N, Awano T, Banasiak A, Bourquin V, Ibatullin F, Funada R, Brumer H, Teeri TT, Hayashi T, Sundberg B, Mellerowicz EJ (2007) Xyloglucan endo-transglycosylase (XET) functions in gelatinous layers of tension wood fibers in poplar-a glimpse into the mechanism of the balancing CCT of trees. Plant Cell Physiol 48:843-855

94. Baba K, Park YW, Kaku T, Kaida R, Takeuchi M, Yoshida M, Hosoo Y, Ojio Y, Okuyama T, Taniguchi T (2009) Xyloglucan for generating tensile stress to bend tree stem. Mol Plant 2:893-903

95. Goswami L, Dunlop JWC, Jungnikl K, Eder M, Gierlinger N, Coutand C, Jeronimidis G, Fratzl P, Burgert I (2008) Stress generation in the tension wood of poplar is based on the lateral swelling power of the G-layer. Plant J 56:531-538 
96. Clair B, Gril J, Di Renzo F, Yamamoto H, Quignard F (2008) Characterization of a gel in the cell wall to elucidate the paradoxical shrinkage of tension wood. Biomacromolecules 9:494-498

97. Alméras T, Clair B (2016) Critical review on the mechanisms of maturation stress generation in trees. J R Soc Interface 13:20160550. doi:10.1098/rsif.2016.0550

98. Boyd JD, Schuster KB (1972) Tree growth stresses. IV. Viscoelastic strain recovery. Wood Sci Technol 6:95-120

99. Kübler H (1959) Studien über wachstumsspannungen des holzes III. Längenänderungen bei der wärmebehandlung frischen holzes (in German). Holz Roh-Werk 17:77-86

100. Gril J, Berrada E, Thibaut B (1993) Recouvrance hygrothermique du bois vert II. Variations dans le plan transverse chez le Châtaignier et l'Epicéa et modélisation de la fissuration à coeur induite par l'étuvage (Hygrothermal recovery of green wood. II. Transverse variations in chestnut and spruce and modelling of the steaming-induced heart checking). Ann Sci For 50:487-508

101. Kübler H (1988) Growth stresses and related wood properties. For Prod Abs 10:61-119

102. Goring DAI (1963) Thermal softening of lignin, hemicellulose and cellulose. Pulp Pap Mag Can 64:T517-T527

103. Tejada A, Okuyama T, Yamamoto H, Yoshida M, Imai T, Itoh T (1998) Studies on the softening point of wood powder as a basis for understanding the release of residual growth stress in logs. For Prod J 48:84-90

104. Koehler A (1933) Effect of heating wet wood on its subsequent dimensions. Am Wood Preserv Assoc 29:376-388

105. Mac Lean JD (1952) Effect of temperature on the dimensions of green wood. Am Wood Preserv Assoc 48:376-388

106. Grzeczynsky T (1962) Einfluss der Erwärmung im Wasser auf vorübergehende und bleibende Formänderungen frischen Rotbuchen-Holzes (in German). Holz Roh-Werk 20:210-216

107. Yokota T, Tarkow H (1962) Changes in dimension on heating green wood. For Prod J 12:43-45

108. Sasaki Y, Okuyama T (1983) Residual stress and dimensional change on heating green wood. Mokuzai Gakkaishi 29:302-307

109. Gril J, Berrada E, Thibaut B, Martin G (1993) Recouvrance hygrothermique du bois vert I. Influence de la température. Cas du jujubier (Ziziphus lotus (L) Lam) (in French). Ann Sci For 50:57-70

110. Jullien D, Gril J (1996) Mesure des déformations bloquées dans un disque de bois vert. Méthode de la fermeture (in French). Ann Sci For 53:955-966

111. Clair B (2012) Evidence that release of internal stress contributes to drying strains of wood. Holzforschung 66:349-353

112. Sujan KC, Yamamoto H, Matsuo M, Yoshida M, Naito K, Shirai $\mathrm{T}$ (2015) Continuum contraction of tension wood fiber induced by repetitive hygrothermal treatment. Wood Sci Technol 49:1157-1169

113. Sujan KC, Yamamoto H, Matsuo M, Yoshida M, Naito K, Suzuki Y, Yamashita N, Yamaji FM (2016) Is hygrothermal recovery of tension wood temperature-dependent? Wood Sci Technol 50:759-772

114. Tanaka M, Yamamoto H, Kojima M, Yoshida M, Matsuo M, Lahjie AM, Hongo I, Arizono T (2014) The interrelation between microfibril angle (MFA) and hygrothermal recovery in compression wood and normal wood of sugi and agathis. Holzforschung 68:823-830

115. Tanaka M, Yamamoto H, Yoshida M, Matsuo M, Lahjie AM (2015) Retarded recovery of remaining growth stress in Agathis wood specimen caused by drying and subsequent re-swelling treatments. Eur J Wood Prod 73:289-298

116. Matsuo MU, Niimi G, Sujan KC, Yoshida M, Yamamoto H (2016) Hygrothermal recovery of compression wood in relation to elastic growth stress and its physicochemical characteristics. J Mater Sci 51:7956-7965

117. Bardet S, Gril J, Kojiro K (2012) Thermal strain of green hinoki wood. Separating the hygrothermal recovery and the reversible deformation. In: Frémond M, Maceri F (eds) Lecture notes in applied and computational mechanics, vol 61. Springer, Berlin, pp $157-162$

118. Gril J, Fournier M (1993) Contraintes d'élaboration du bois dans l'arbre: un modèle multicouche viscoélastique (in French). In: 11ème Congrès Français de Mécanique, vol 4. Association Universitaire de Mécanique, Lille-Villeneuve d'Ascq, pp 165-168

119. Bardet S, Gril J (2002) Modelling the transverse viscoelasticity of green wood using a combination of two parabolic elements. C R Acad Sci Sér 2B(330):549-556

120. Vincent P, Bardet S, Tordjeman P, Gril J (2004) Influence of temperature on the torsional behaviour of small clear-wood specimens in green state. In: Morlier P, Morais J, Dourado N (eds) Proceedings of the third international conference of the European Society for Wood Mechanics. UTAD, Vila Real, pp 119-124

121. Dlouhá J, Clair B, Arnould O, Horáček P, Gril J (2009) On the time-temperature equivalency in green wood: characterisation of viscoelastic properties in longitudinal direction. Holzforschung 63:327-333

122. Gril J (1991) Maturation et viscoelasticité du bois en croissance et recouvrance hygrothermique (in French). In: Thibaut B (ed) 3ème séminaire architecture. Structure et Mécanique de l'Arbre, Montpellier, pp 153-158

123. Gril J (1992) Rheology of in-tree wood and hygrothermal recovery. In: Abstract of IUFRO all division 5 conference. Arbolor, Nancy, p 185

124. Guitard D (1987) Mécanique du matériau bois et composites (in French). Coll. Nabla, Cepadues-éditions, Toulouse

125. Bandyopadhyay N, Archer RR (1979) Relief of growth stress in planks. Holzforschung 33:43-46

126. Okuyama T, Sasaki Y (1979) Crooking during lumbering due to residual stresses in the tree. Mokuzai Gakkaishi 25:681-687

127. Maeglin RR (1987) Juvenile wood, tension wood, and growth stress effects on processing hardwoods. Applying the latest research to hardwood problems (proceedings of the 15th annual hardwood symposium of the Hardwood Research Council). Hardwood Res Council, Memphis, pp 100-108

128. Jullien D, Laghdir A, Gril J (2003) Modelling log-end cracks due to growth stresses: calculation of the elastic energy release rate. Holzforschung 57:407-414

129. Yang JL (2005) The impact of log-end splits and spring on sawn recovery of 32-year-old plantation Eucalyptus globulus Labill. Holz Roh-Wer 63:442-448

130. Clair B, Thibaut B (2014) Physical and mechanical properties of reaction wood. In: Gardiner B, Barnett J, Saranpää P, Gril J (eds) The biology of reaction wood. Springer, Berlin, pp 171-200

131. Gardiner B, Flatman T, Thibaut B (2014) Commercial implication of reaction wood and the influence of forest management. In: Gardiner B, Barnett J, Saranpää P, Gril J (eds) The biology of reaction wood. Springer, Berlin, pp 249-274

132. Okuyama T, Doldan D, Yamamoto H, Ona T (2004) Heart splitting at crosscutting of Eucalyptus grandis logs. J Wood Sci $50: 1-6$

133. Jullien D, Gril J (2002) Modelling crack propagation due to growth stress release in round wood. J Phys IV 105:265-272

134. Maeglin RR, Liu JY, Boone S (1985) High-temperature drying and equalizing: effects on stress relief in yellow poplar lumber. Wood Fiber Sci 17:240-253 
135. Okuyama T, Kanagawa Y, Hattori Y (1987) Reduction of residual stresses in logs by direct heating method. Mokuzai Gakkaishi 33:837-843

136. Tejada A, Okuyama T, Yamamoto H, Yoshida M (1997) Reduction of growth stress in logs by direct heat treatment. Assessment of a commercial-scale operation. For Prod J 47:88-93

137. Okuyama T, Yamamoto H (1992) The residual stresses in living tree. In: Fujiwara H, Tabe T, Tanaka K (eds) Residual stressesIII. Elsevier, Barking, pp 128-133
138. Nogi M, Yamamoto H, Okuyama T (2003) Relaxation mechanism of residual stresses inside logs by heat treatment: deciding of the heating time and temperature to release residual stresses. J Wood Sci 49:22-28

139. Huang YS, Chen SS, Kuo-Huang LL, Lee MC (2005) Growth stress of Zelkova serrata and its reduction by heat treatment. For Prod J 55:88-93

140. Severo ETD, Calonego FW, Matos CAO (2010) Lumber quality of Eucalyptus grandis as a function of diametrical position and log steaming. Bioresour Technol 101:2545-2548 